Supporting information:

\title{
Fast Ion-Chelate Dissociation Rate for In Vivo MRI of Labile Zinc with Frequency-Specific Encodability
}

Nishanth D. Tirukoti ${ }^{1}$, Liat Avram², Talia Haris ${ }^{2}$, Benjamin Lerner ${ }^{1}$, Yael DiskinPosner $^{2}$, Hyla Allouche-Arnon ${ }^{1}$, Amnon Bar-Shir ${ }^{1 *}$

1Department of Molecular Chemistry and Materials Science, Weizmann Institute of Science, Rehovot 7610001, Israel.

2Department of Chemical Research Support, Weizmann Institute of Science, Rehovot 7610001, Israel.

*Corresponding Author: amnon.barshir@weizmann.ac.il

\section{$\underline{\text { Table of contents }}$}

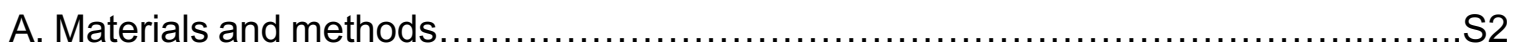

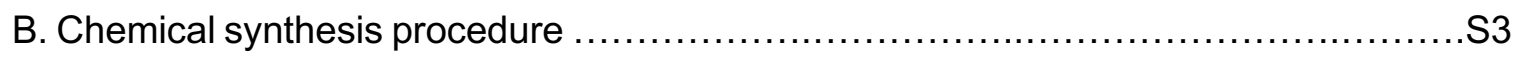

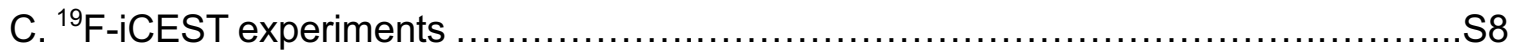

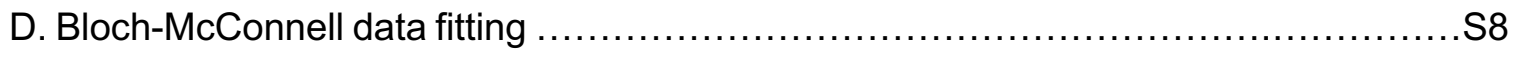

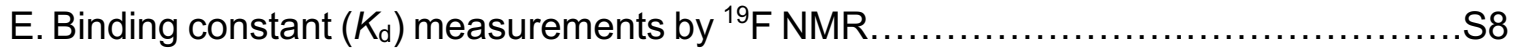

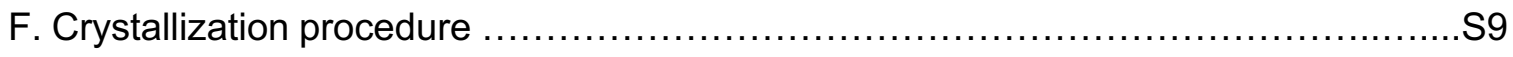

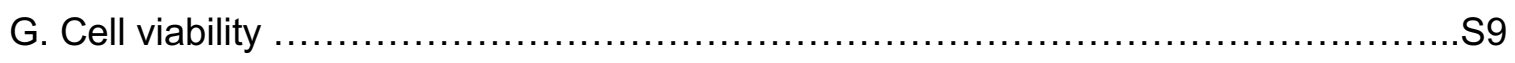

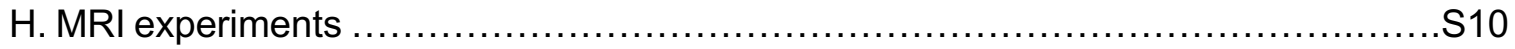

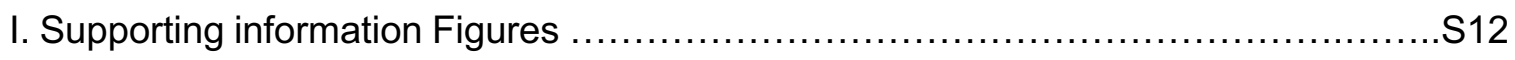

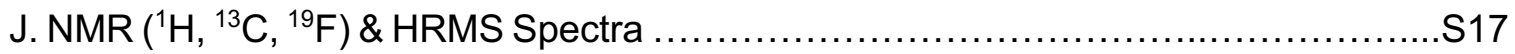

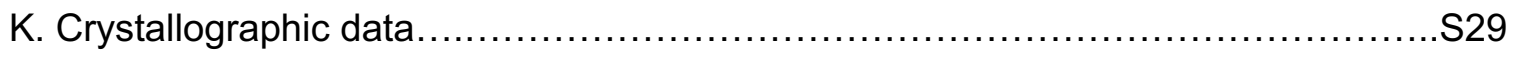

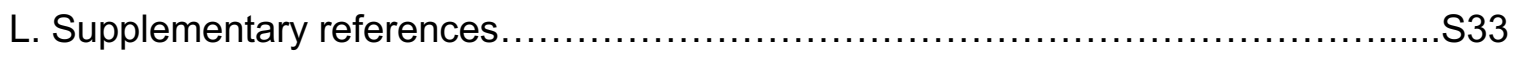




\section{A. Materials and Methods}

All the reagents and solvents were obtained from commercial suppliers. Fluoropicolinaldehydes, such as 3- fluoropicolinaldehyde, 5fluoropicolinaldehyde, and 6- fluoropicolinaldehyde, were purchased from Oxchem Corporation Chemicals (Wood Dale, IL). 5- fluoro-6-methylpicolinaldehyde, 2-(5fluoropyridin-2-yl)ethan-1-ol, and 2-(5-fluoro-6-methylpyridin-2-yl)ethan-1-ol were purchased from Pharma Block Sciences, Inc. (Nanjing, China). Sodium triacetoxyborohydride and sodium sulphate were purchased from Alfa Aesar. Dipicolylamine (DPA) was purchased from Sigma Aldrich. Deuterated solvents, such as $\mathrm{CDCl}_{3}$ and $\mathrm{D}_{2} \mathrm{O}$, were purchased from Cambridge Isotope Laboratories, Inc. (Andover, MA). The ${ }^{1} \mathrm{H}$ NMR, ${ }^{13} \mathrm{C}$ NMR, ${ }^{19} \mathrm{~F}$ NMR spectra, ${ }^{19} \mathrm{~F}-\mathrm{NMR} \mathrm{Zn}^{2+}$ binding studies, and ${ }^{19} \mathrm{~F}$-iCEST experiments were performed on a Bruker AVANCE III 9.4 T NMR spectrometer. The following abbreviations are used to describe peaks: s-singlet; d- doublet; t-triplet; $\mathrm{m}$ - multiplet. High-resolution mass spectrometry (HR-MS) was recorded on an AB SCIEX 5800 MALDI TOF instrument at the Weizmann institute of Science mass spectrometry facility. Phantom magnetic resonance imaging (MRI) experiments were performed on a 9.4 T wide-bore MR scanner (Bruker AVANCE III system). A $25 \mathrm{~mm}$, doubleresonant $\left({ }^{1} \mathrm{H} /{ }^{19} \mathrm{~F}\right)$ radiofrequency (RF) coil was used to acquire ${ }^{1} \mathrm{H},{ }^{19} \mathrm{~F}$, and ${ }^{19} \mathrm{~F}$ iCEST MR images. For animal surgeries, a customized stereotaxic surgery setup was used, with $2 \mathrm{~mm}$ and $3.5 \mathrm{~mm}$ MRI-compatible cannulas that were purchased from p1 Technologies (Roanoke, Virginia, USA). Animal MRI experiments were performed on a Bruker BioSpec 15.2 T AVANCE III HD imaging spectrometer. A dual ${ }^{1} \mathrm{H} /{ }^{19} \mathrm{~F}, 23 \mathrm{~mm}$ RF coil was used to acquire the ${ }^{1} \mathrm{H},{ }^{19} \mathrm{~F}-\mathrm{MR}$, and ${ }^{19} \mathrm{~F}$-iCEST images. For the details of $\mathrm{X}$-ray data collection and refinement, see section $\mathrm{K}$. 


\section{B. Chemical Synthesis procedure}

\section{Compound 1:}<smiles>O=Cc1cccc(F)n1</smiles>
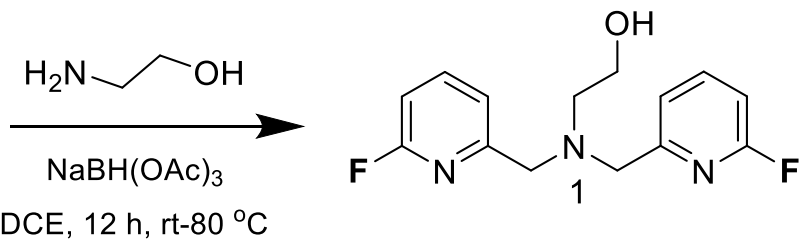

DCE, $12 \mathrm{~h}, \mathrm{rt}-80^{\circ} \mathrm{C}$

6-fluoropicolinaldhyde (166.40 $\mathrm{mg}, 1.33 \mathrm{mmol}$ ) was added to a solution of 2aminoethan-1-ol (32.5 mg, $532.05 \mu \mathrm{mol})$ in 1,2-dichloroethane (DCE) $(8 \mathrm{~mL})$ and stirred at room temperature for $30 \mathrm{~min}$ followed by the addition of sodium triacetoxyborohydride (338 $\mathrm{mg}, 1.59 \mathrm{mmol}$ ). The reaction mixture was then stirred at room temperature for an additional $1 \mathrm{~h}$ before being heated to $80^{\circ} \mathrm{C}$ for $12 \mathrm{~h}$. Completion of the reaction was confirmed by thin layer chromatography (TLC) and the solvent was evaporated under reduced pressure. The crude product was dissolved in $\mathrm{CHCl}_{3}$, washed with a saturated solution of $\mathrm{NaHCO}_{3}$ and extracted with $\mathrm{CHCl}_{3}(2 \times 20 \mathrm{~mL})$, then the combined organic phase was dried over $\mathrm{Na}_{2} \mathrm{SO}_{4}$. Following filtration, the organic phase was concentrated and purified using silica gel column chromatography $\left(\mathrm{CHCl}_{3} / \mathrm{MeOH}, 95: 5\right)$ to obtain compound 1 as a pale yellow oil (122 mg, 83\%). ${ }^{1} \mathrm{H}$ NMR (400.35 MHz, $\left.\mathrm{CDCl}_{3}\right)$ : $\delta 7.72(\mathrm{~m}, 2 \mathrm{H}), 7.28$ (d, $\left.J_{H-F}=7.5 \mathrm{~Hz}, 2 \mathrm{H}\right), 6.78\left(\mathrm{~d}, J_{H-F}=8.4 \mathrm{~Hz}, 2 \mathrm{H}\right), 3.86(\mathrm{~s}, 4 \mathrm{H}), 3.66(\mathrm{t}, J=5.2 \mathrm{~Hz}, 2 \mathrm{H})$, 2.84 (t, J=5.2 Hz, 2H). ${ }^{13} \mathrm{C}\left\{{ }^{1} \mathrm{H}\right\}\left(100.67 \mathrm{MHz}, \mathrm{CDCl}_{3}\right) \delta 163.0$ (d, JC-F $\left.=240 \mathrm{~Hz}\right)$, $158.1\left(\mathrm{~d}, J_{C-F}=12.4 \mathrm{~Hz}\right), 141.5\left(\mathrm{~d}, J_{C-F}=7.7 \mathrm{~Hz}\right), 120.2\left(\mathrm{~d}, J_{C-F}=4.1 \mathrm{~Hz}\right), 107.7$ $\left(\mathrm{d}, J_{C-F}=36.5 \mathrm{~Hz}\right), 59.2,59.1,56.5 .{ }^{19} \mathrm{~F}\left(376.7 \mathrm{MHz}, \mathrm{CDCl}_{3}\right) \delta-68.25(\mathrm{~m}) . \mathrm{HRMS}$ (ESI) calculated for $\mathrm{C}_{14} \mathrm{H}_{15} \mathrm{~F}_{2} \mathrm{~N}_{3} \mathrm{NaO}[\mathrm{M}+\mathrm{Na}] \mathrm{m} / \mathrm{z} 302.1081$, found $\mathrm{m} / \mathrm{z} 302.1087$.

\section{Compound 2:}<smiles>O=Cc1ncccc1F</smiles><smiles>CCO[R10](=O)OCC</smiles><smiles>OCCN(Cc1ncccc1F)Cc1ncccc1F</smiles> 
3-fluoropicolinaldhyde $(101.5 \mathrm{mg}, 0.881 \mathrm{mmol})$ was added to a solution of 2aminoethan-1-ol (20 mg, $372 \mu \mathrm{mol})$ in 1,2-dichloroethane $(5 \mathrm{~mL})$ and stirred at room temperature for $30 \mathrm{~min}$ followed by the addition of sodium triacetoxyborohydride $(316 \mathrm{mg}, 1.1 \mathrm{mmol})$. The reaction mixture was then stirred at room temperature for an additional $1 \mathrm{~h}$ before being heated to $80^{\circ} \mathrm{C}$ for $12 \mathrm{~h}$. Completion of the reaction was confirmed by TLC and the solvent was evaporated. The crude product was dissolved in $\mathrm{CHCl}_{3}$, washed with a saturated solution of $\mathrm{NaHCO}_{3}$ and extracted with $\mathrm{CHCl}_{3}(2 \times 20 \mathrm{~mL})$, and the combined organic phase was dried over $\mathrm{Na}_{2} \mathrm{SO}_{4}$. Following filtration, the organic phase was concentrated and purified using a silica gel column $\left(\mathrm{CHCl}_{3} / \mathrm{MeOH}, 95: 5\right)$ to obtain compound 2 as a pale-yellow oil (81 mg, $90 \%) .{ }^{1} \mathrm{H}$ NMR $\left(400.35 \mathrm{MHz}, \mathrm{CDCl}_{3}\right): \delta 8.42(\mathrm{~m}, 2 \mathrm{H})$, $7.39(\mathrm{~m}, 2 \mathrm{H}), 7.27(\mathrm{~m}, 2 \mathrm{H}), 4.14(\mathrm{~m}, 4 \mathrm{H}), 3.7$ (t, J=5 Hz, 2H), 2.97 (t, J=5 Hz, 2H). ${ }^{13} \mathrm{C}\left\{{ }^{1} \mathrm{H}\right\}\left(100.67 \mathrm{MHz}, \mathrm{CDCl}_{3}\right) \delta 158.2\left(\mathrm{~d}, J_{C-F}=258.8 \mathrm{~Hz}\right), 147.1\left(\mathrm{~d}, J_{C-F}=14.1\right.$ $\mathrm{Hz}), 144.6\left(\mathrm{~d}, J_{C-F}=5.7 \mathrm{~Hz}\right), 123.6\left(\mathrm{~d}, J_{C-F}=3.7 \mathrm{~Hz}\right), 122.9\left(\mathrm{~d}, J_{C-F}=20 \mathrm{~Hz}\right), 59.3$, 56.1, 53.6. ${ }^{19} \mathrm{~F}\left(376.7 \mathrm{MHz}, \mathrm{CDCl}_{3}\right) \delta-125.74\left(\mathrm{~d}, J_{F-H}=8.7 \mathrm{~Hz}\right)$. HRMS (ESI) calculated for $\mathrm{C}_{14} \mathrm{H}_{16} \mathrm{~F}_{2} \mathrm{~N}_{3} \mathrm{O}[\mathrm{M}+\mathrm{H}] \mathrm{m} / \mathrm{z} 280.1261$, found $\mathrm{m} / \mathrm{z} 280.1265$.

\section{Compound 3 :}

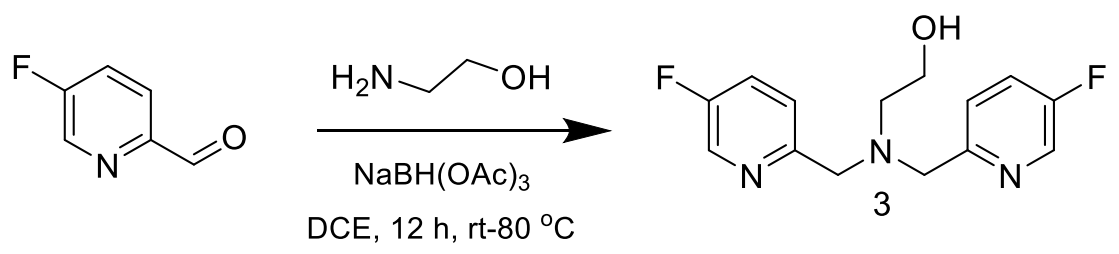

5-fluoropicolinaldhyde (180 mg, $1.43 \mathrm{mmol}$ ) was added to a solution of 2aminoethan-1-ol (35 mg, $372 \mu \mathrm{mol})$ in 1,2-dichloroethane $(10 \mathrm{~mL})$ and stirred at room temperature for $30 \mathrm{~min}$ followed by the addition of sodium triacetoxyborohydride $(362 \mathrm{mg}, 1.7 \mathrm{mmol})$. The reaction mixture was then stirred at room temperature for an additional $1 \mathrm{~h}$ before being heated up to $80^{\circ} \mathrm{C}$ for 12 h. Completion of the reaction was confirmed by TLC and the solvent was 
evaporated. The crude product was dissolved in $\mathrm{CHCl}_{3}$, washed with a saturated solution of $\mathrm{NaHCO}_{3}$ and extracted with $\mathrm{CHCl}_{3}(2 \times 20 \mathrm{~mL})$, and the combined organic phase was dried over $\mathrm{Na}_{2} \mathrm{SO}_{4}$. Following filtration, the organic phase was concentrated and purified using a silica gel column $\left(\mathrm{CHCl}_{3} / \mathrm{MeOH}, 95: 5\right)$ to obtain compound 3 as a pale white yellowish solid (144 mg, 90\%). ${ }^{1} \mathrm{H}$ NMR $(400.35 \mathrm{MHz}$, $\mathrm{CDCl}_{3}$ ): $\delta 8.46(\mathrm{~s}, 2 \mathrm{H}), 7.40(\mathrm{~m}, 4 \mathrm{H}), 3.90(\mathrm{~s}, 4 \mathrm{H}), 3.67$ (t, J=5.1 Hz, 2H), 2.85 (t, $J=5.1 \mathrm{~Hz}, 2 \mathrm{H}) .{ }^{13} \mathrm{C}\left\{{ }^{1} \mathrm{H}\right\}\left(100.7 \mathrm{MHz}, \mathrm{CDCl}_{3}\right) \delta 158.6\left(\mathrm{~d}, J_{\mathrm{C}-F}=255 \mathrm{~Hz}\right), 155.1(\mathrm{~d}$, $\left.J_{C-F}=3.4 \mathrm{~Hz}\right), 137.1\left(\mathrm{~d}, J_{C-F}=23.6 \mathrm{~Hz}\right), 123.9\left(\mathrm{~d}, J_{C-F}=4.18 \mathrm{~Hz}\right), 123.3\left(\mathrm{~d}, J_{C-F}=\right.$ $18.3 \mathrm{~Hz}), 59.5,59.2,56.5{ }^{19} \mathrm{~F}\left(376.7 \mathrm{MHz}, \mathrm{CDCl}_{3}\right) \delta-130.6\left(\mathrm{t}, J_{F-H}=6 \mathrm{~Hz}\right)$. HRMS (ESI) calculated for $\mathrm{C}_{14} \mathrm{H}_{16} \mathrm{~F}_{2} \mathrm{~N}_{3} \mathrm{O}[\mathrm{M}+\mathrm{H}] \mathrm{m} / \mathrm{z} 280.1261$, found $\mathrm{m} / \mathrm{z} 280.1268$.

\section{Compound 4:}

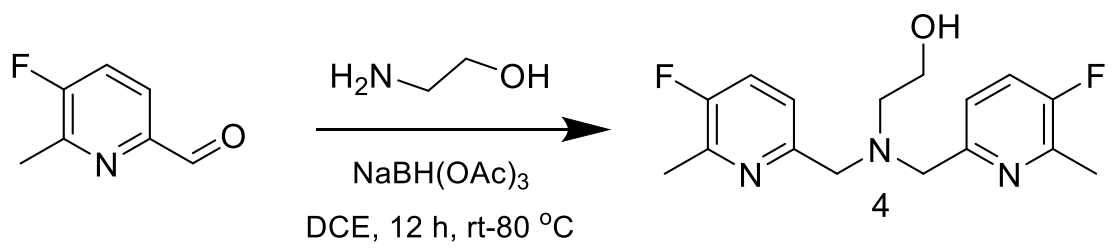

5-fluoro-6-methylpicolinaldhyde $(171 \mathrm{mg}, 1.23 \mathrm{mmol}$ ) was a added to a solution of 2-aminoethan-1-ol (30 mg, $491 \mu \mathrm{mol})$ in 1,2-dichloroethane $(10 \mathrm{~mL})$ and stirred at room temperature for $30 \mathrm{~min}$ followed by the addition of sodium triacetoxyborohydride $(310 \mathrm{mg}, 1.4 \mathrm{mmol})$. The reaction mixture was then stirred at room temperature for an additional $1 \mathrm{~h}$ before being heated to $80^{\circ} \mathrm{C}$ for $12 \mathrm{~h}$. Completion of the reaction was confirmed by TLC and the solvent was evaporated. The crude product was dissolved in $\mathrm{CHCl}_{3}$, washed with a saturated solution of $\mathrm{NaHCO}_{3}$ and extracted with $\mathrm{CHCl}_{3}(2 \times 20 \mathrm{~mL})$, and the combined organic phase was dried over $\mathrm{Na}_{2} \mathrm{SO}_{4}$. Following filtration, the organic phase was concentrated and purified using silica gel column chromatography $\left(\mathrm{CHCl}_{3} / \mathrm{MeOH}, 97: 3\right)$ to obtain compound 4 as a pale yellow solid (138 mg, 92\%). ${ }^{1} \mathrm{H} \mathrm{NMR}\left(400.35 \mathrm{MHz}, \mathrm{CDCl}_{3}\right)$ : $\delta 7.32(\mathrm{~m}, 2 \mathrm{H}), 7.24(\mathrm{~m}, 2 \mathrm{H}), 3.93(\mathrm{~s}, 4 \mathrm{H}), 3.74(\mathrm{t}, J=4.9 \mathrm{~Hz}, 2 \mathrm{H}), 2.92(\mathrm{t}, J=4.9 \mathrm{~Hz}$, 2H), $2.59(\mathrm{~s}, 6 \mathrm{H}) .{ }^{13} \mathrm{C}\left\{{ }^{1} \mathrm{H}\right\}\left(100.67 \mathrm{MHz}, \mathrm{CDCl}_{3}\right) \delta 156.9\left(\mathrm{~d}, J_{\mathrm{C}-\mathrm{F}}=253.3 \mathrm{~Hz}\right), 154.0$ $\left(\mathrm{d}, J_{C-F}=5.05 \mathrm{~Hz}\right), 145.9\left(\mathrm{~d}, J_{C-F}=17 \mathrm{~Hz}\right), 122.7\left(\mathrm{~d}, J_{C-F}=19.6 \mathrm{~Hz}\right), 121.5\left(\mathrm{~d}, J_{C-}\right.$ 
$F=3.75 \mathrm{~Hz}), 59.6,59.3,56.6,17.8 .{ }^{19} \mathrm{~F}\left(376.7 \mathrm{MHz}, \mathrm{CDCl}_{3}\right) \delta-128.60(\mathrm{~m}) . \mathrm{HRMS}$ (ESI) calculated for $\mathrm{C}_{16} \mathrm{H}_{19} \mathrm{~F}_{2} \mathrm{~N}_{3} \mathrm{NaO}[\mathrm{M}+\mathrm{Na}] \mathrm{m} / \mathrm{z} 330.1394$, found $\mathrm{m} / \mathrm{z} 330.1400$.

\section{Compound 5a, 5:}

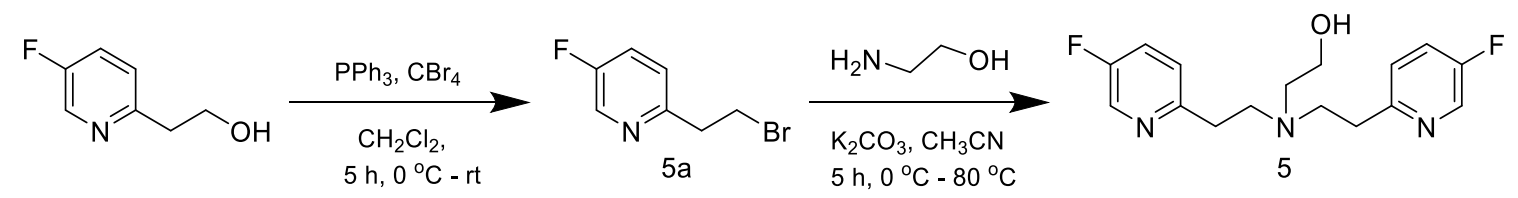

5a :To a solution of 2-(5-fluoropyridin-2-yl)ethan-1-ol $(250 \mathrm{mg}, 1.77 \mathrm{mmol})$ in $\mathrm{CH}_{2} \mathrm{Cl}_{2}(5 \mathrm{~mL}), \mathrm{PPh}_{3}(1.39 \mathrm{~g}, 5.31 \mathrm{mmol})$ was added followed by $\mathrm{CBr}_{4}(1.76 \mathrm{~g}, 5.31$ $\mathrm{mmol}$ ) at $0{ }^{\circ} \mathrm{C}$. The reaction mixture was stirred at room temperature for $2 \mathrm{~h}$. Completion of the reaction was confirmed by TLC, solvent was removed under reduced pressure and the resulting residue was purified by silica gel column chromatography (EtOAc/Petroleum ether, 5:95) to obtain compound $\mathbf{5 a}$ as yellow oil (260 mg, 72\%). LC/MS (ES, m/z) [M+H]: 203.

5 :Compound 5 a (260 mg ,1.27 mmol) was added to a solution of 2-aminoetha1-ol (31 mg, $507.50 \mu \mathrm{mol})$ in $\mathrm{CH}_{3} \mathrm{CN}\left(3 \mathrm{~mL}\right.$ ) and stirred for 5 min under $\mathrm{N}_{2}$ at room temperature. This was followed by addition of potassium carbonate $(210 \mathrm{mg}, 1.52$ $\mu \mathrm{mol})$, then the reaction mixture was heated to $80^{\circ} \mathrm{C}$ for $5 \mathrm{~h}$. Completion of the reaction was confirmed by TLC and the solvent was evaporated under reduced pressure. The crude product was dissolved in $\mathrm{CHCl}_{3}$, washed with brine solution and extracted with $\mathrm{CHCl}_{3}(2 \times 20 \mathrm{~mL})$, and the combined organic phase was dried over $\mathrm{Na}_{2} \mathrm{SO}_{4}$. Following filtration, the organic phase was concentrated and purified using a silica gel column $\left(\mathrm{CHCl}_{3} / \mathrm{MeOH} 95: 5\right)$ to obtain compound 5 as yellow oil (120 mg, 77\%). ${ }^{1} \mathrm{H}$ NMR (400.35 MHz, $\mathrm{CDCl}_{3}$ ): $\delta 8.41$ (d, $\left.J_{H-F}=2.79 \mathrm{~Hz}, 2 \mathrm{H}\right), 7.3$ (m, 2H), $7.0(\mathrm{~m}, 2 \mathrm{H}), 3.62(\mathrm{t}, J=5 \mathrm{~Hz}, 2 \mathrm{H}), 2.99(\mathrm{t}, J=6.2 \mathrm{~Hz}, 4 \mathrm{H}), 2.91(\mathrm{t}, J=6.2$ $\mathrm{Hz}, 4 \mathrm{H}), 2.79(\mathrm{t}, J=5 \mathrm{~Hz}, 2 \mathrm{H}) \cdot{ }^{13} \mathrm{C}\left\{{ }^{1} \mathrm{H}\right\}\left(100.67 \mathrm{MHz}, \mathrm{CDCl}_{3}\right) \delta 158.1\left(\mathrm{~d}, J_{C-F}=\right.$ $254.1 \mathrm{~Hz}$ ), $156.2\left(\mathrm{~d}, J_{C-F}=4.0 \mathrm{~Hz}\right.$ ), $137.0\left(\mathrm{~d}, J_{C-F}=23.4 \mathrm{~Hz}\right.$ ), 124.01 (d, $J_{C-F}=3.8$ $\mathrm{Hz}), 123.0\left(\mathrm{~d}, J_{\mathrm{C}-\mathrm{F}}=18.2 \mathrm{~Hz}\right), 59.3,55.9,53.8,35.0 .{ }^{19} \mathrm{~F}\left(376.7 \mathrm{MHz}, \mathrm{CDCl}_{3}\right):-$ 
$131.6\left(\mathrm{t}, J_{F-H}=6 \mathrm{~Hz}\right)$ HRMS $(\mathrm{ESI})(\mathrm{m} / \mathrm{z}):[\mathrm{M}+\mathrm{Na}]$ calcd for $\mathrm{C}_{16} \mathrm{H}_{19} \mathrm{~F}_{2} \mathrm{~N}_{3} \mathrm{NaO}$ 330.1394 , found 330.1389 .

\section{Compound 6a, 6 :}

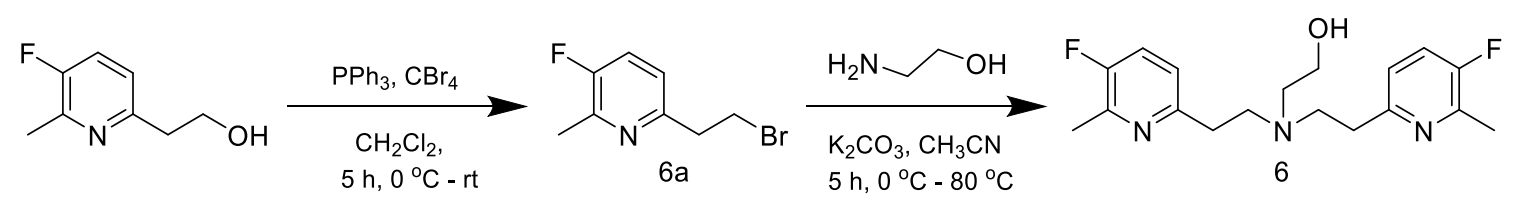

6a: To a solution of 2-(5-fluoro-6-methylpyridin-2yl)ethan-1-ol (250 mg, $1.61 \mathrm{mmol})$ in $\mathrm{CH}_{2} \mathrm{Cl}_{2}(5 \mathrm{~mL}), \mathrm{PPh}_{3}(1.06 \mathrm{~g}, 4.03 \mathrm{mmol})$ was added followed by $\mathrm{CBr}_{4}(1.34 \mathrm{~g}$, $4.03 \mathrm{mmol}$ ) at $0{ }^{\circ} \mathrm{C}$. The reaction mixture was stirred at room temperature for $6 \mathrm{~h}$, and completion of the reaction was confirmed by TLC. The solvent was removed under reduced pressure, and the resulting residue was purified by silica gel column chromatography (EtOAc/Petroleum ether, 5:95) to obtain compound $\mathbf{6 a}$ as yellow oil $(260 \mathrm{mg}, 74 \%)$. LC/MS (ES, m/z) [M+H]: 219.

6: Compound $6 \mathbf{a}(260 \mathrm{mg}, 1.20 \mathrm{mmol}$ ) was added to a solution of 2-aminoetha-1ol (32 mg, $523.87 \mu \mathrm{mol})$ in $\mathrm{CH}_{3} \mathrm{CN}(3 \mathrm{~mL})$ and stirred under $\mathrm{N}_{2}$ for $5 \mathrm{~min}$ at room temperature followed by addition of potassium carbonate $(217.20 \mathrm{mg}, 1.57 \mu \mathrm{mol})$, then the reaction mixture was heated to $80^{\circ} \mathrm{C}$ for $5 \mathrm{~h}$. Completion of the reaction was confirmed by TLC and the solvent was evaporated. The crude product was dissolved in $\mathrm{CHCl}_{3}$, washed with brine solution and extracted with $\mathrm{CHCl}_{3}(2 \times 20$ $\mathrm{mL}$ ), and the combined organic phase was dried over $\mathrm{Na}_{2} \mathrm{SO}_{4}$. Following filtration, the organic phase was concentrated and purified using a silica gel column chromatography (EtOAC/Petroleum ether 80:20) to obtain compound 6 as yellowish white solid (130 mg, 74\%). ${ }^{1} \mathrm{H}$ NMR $\left(400.35 \mathrm{MHz}, \mathrm{CDCl}_{3}\right) \delta 7.22\left(\mathrm{t}, \mathrm{J}_{\mathrm{H}-\mathrm{F}}\right.$ $=8.62 \mathrm{~Hz}, 2 \mathrm{H}), 6.86(\mathrm{~m}, 2 \mathrm{H}), 3.63(\mathrm{t}, J=4.6 \mathrm{~Hz}, 2 \mathrm{H}), 2.97(\mathrm{t}, J=6.6 \mathrm{~Hz}, 4 \mathrm{H}), 2.86$ (t, $J=6.6 \mathrm{~Hz}, 4 \mathrm{H}), 2.79(\mathrm{t}, J=4.6 \mathrm{~Hz}, 2 \mathrm{H}), 2.54(\mathrm{~s}, 6 \mathrm{H}) .{ }^{13} \mathrm{C}\left\{{ }^{1} \mathrm{H}\right\}(100.67 \mathrm{MHz}$, $\left.\mathrm{CDCl}_{3}\right) \delta$ 157.6, $155.1\left(\mathrm{~d}, J_{\mathrm{C}-F}=4.7 \mathrm{~Hz}\right), 145.6\left(\mathrm{~d}, J_{C-F}=16.5 \mathrm{~Hz}\right), 122.3\left(\mathrm{~d}, J_{C-F}=\right.$ $19.2 \mathrm{~Hz}), 121.6\left(\mathrm{~d}, J_{C-F}=3.5 \mathrm{~Hz}\right), 59.4,56.1,54.1,35.0,17.7 .{ }^{19} \mathrm{~F}(376.7 \mathrm{MHz}$, $\left.\mathrm{CDCl}_{3}\right)$ : $-130.2(\mathrm{~m})$. [M+H] calcd for $\mathrm{C}_{18} \mathrm{H}_{24} \mathrm{~F}_{2} \mathrm{~N}_{3} \mathrm{O} 336.1887$, found 336.1882 . 


\section{C. ${ }^{19} \mathrm{~F}$-iCEST NMR experiments}

All ${ }^{19} \mathrm{~F}$-iCEST NMR experiments were performed on a 9.4 T MHz AVANCEIII NMR spectrometer (Bruker, Germany), with the sample temperature stabilized at $310 \mathrm{~K}$. A pre-saturation pulse ( $t_{\text {sat }}$ ) with a length of $2 \mathrm{sec}$ and a pulse strength $100 \mathrm{~Hz}$ were applied prior to the $90^{\circ} \mathrm{RF}$ pulse. The frequency of the $B_{1}$ was swept from $\Delta \omega=+8$ ppm to $\Delta \omega=-8 \mathrm{ppm}$ in $100 \mathrm{~Hz}=0.27 \mathrm{ppm}$ steps relative to the resonance of the free ${ }^{19} \mathrm{~F}$-iCEST sensor (set to $0 \mathrm{ppm}$ for convenience). Each frequency offset $(\Delta \omega$ $+/-)$ was acquired with eight scans, using a repetition time of $15 \mathrm{sec}$, resulting in total iCEST experiment time of $\sim 2 \mathrm{~h} 34 \mathrm{~min}$.

\section{Bloch-McConnell data fitting}

To estimate the exchange rate $\left(k_{e x}\right)$ between $\mathrm{Zn}^{2+}$-bound and free ${ }^{19} \mathrm{~F}$-chelate, multi $B_{1}$ CEST experiments were perfumed with saturation powers ranging from 5 $\mathrm{Hz}$ to $150 \mathrm{~Hz}$. The obtained data (z-spectra) were fitted using the Bloch-McConnell equations ${ }^{1-3}$. Both numerical and analytical simulations, which provided similar $k_{e x}$ values, were performed using a custom-written script in MATLAB version 8.2.0.701 (The MathWorks, Natick, MA). The code for data-fitting can be found at http://www.cest-sources.org/doku.php?id=start.

\section{E. Dissociation constant $\left(K_{d}\right)$ measurements by ${ }^{19} \mathrm{~F}$ NMR}

Since the exchange between $\mathrm{Zn}^{2+}$-bound and free $\mathbf{5}$ is slow in the NMR timescale, the $K_{d}$ values can be evaluated from the ratio between the integrals of the two NMR signals obtained for the free and bound forms (Figure S2). Thus, the dissociation constant $K_{d}$ was determined with the assistant of ${ }^{19} \mathrm{~F}-\mathrm{NMR}$ at $25^{\circ} \mathrm{C}$. To this end, ${ }^{19} \mathrm{~F}-\mathrm{NMR}$ spectra of aqueous solutions (in $100 \mathrm{mM}$ Hhepes buffer, $\mathrm{pH} 7.4$ ) of 1

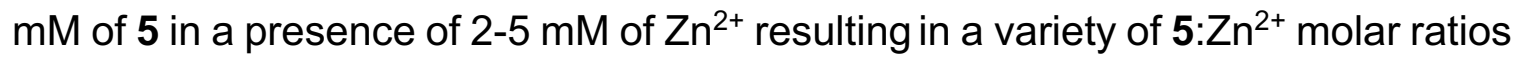
(0.2:1, 0.3:1, 0.35:1, 0.4:1, 0.45:1, 0.5:1, see Table $\mathrm{S} 1$ and representative example in Figure S2) were recorded. Then, the ${ }^{19} \mathrm{~F}-\mathrm{NMR}$ signals of $\mathrm{Zn}^{2+}$-bound $\left(5 \cdot Z n^{2+}\right)$ 
and free $\mathbf{5}$ were integrated and the obtained values were used for $K_{d}$ calculations. In order to measure a true equilibrium constant, the concentrations were varied in order to obtain $20-80 \%$ of the bound form to determine the $K_{d}$ value $\left(K_{d}=5.5 \pm 0.6\right.$ $\left.\times 10^{-3} \mathrm{M}\right)$. See, Table S1 and Figure S2.

$$
\begin{gathered}
\mathbf{5}+Z n^{2+} \rightleftharpoons \mathbf{5} \cdot Z n^{2+} \\
K_{d}=\frac{[\mathbf{5}]\left[\mathrm{Zn}^{2+}\right]}{\left[\mathbf{5} \cdot Z n^{2+}\right]}
\end{gathered}
$$

\section{F. Crystallization procedure}

Compound 3 + Zn Complex: Both Compound 3 (5 mg) and $\mathrm{Zn}\left(\mathrm{ClO}_{4}\right)_{2} \cdot 6 \mathrm{H}_{2} \mathrm{O}(6.6$ $\mathrm{mg}$ ) were dissolved in $50 \mu \mathrm{L} \mathrm{MeOH}$ separately. The obtained solutions were sonicated until they became clear, mixed at room temperature, and left for slow evaporation. After 14 days, a single crystal was obtained for X-ray crystallography analysis.

Compound 4 + $\mathrm{Zn}$ Complex: Both Compound 4 (5 mg) and $\mathrm{Zn}\left(\mathrm{ClO}_{4}\right)_{2} \cdot 6 \mathrm{H}_{2} \mathrm{O}(6 \mathrm{mg})$ were dissolved in $50 \mu \mathrm{L} \mathrm{MeOH}$ separately. The obtained solutions were sonicated until they became clear, mixed at room temperature, and left for slow evaporation. After 14 days, a single crystal suitable for X-ray crystallography analysis was obtained.

Compound 5 + $\mathrm{Zn}$ Complex: Both Compound 5 (5 mg) and $\mathrm{Zn}\left(\mathrm{ClO}_{4}\right)_{2} \cdot 6 \mathrm{H}_{2} \mathrm{O}(6 \mathrm{mg}$ ) were dissolved in $50 \mu \mathrm{L} \mathrm{MeOH}$ separately. The obtained solutions were sonicated until they became clear, mixed at room temperature, and left for slow evaporation. After five days, a single crystal suitable for X-ray crystallography analysis was obtained.

\section{G. Cell Viability}

Cell Titer-Blue assay: Chinese hamster ovary $(\mathrm{CHO})$ cells $\left(12 \times 10^{3}\right.$ cells $\left./ \mathrm{mL}\right)$ were cultured in 96-well microplates with Dulbecco's Modified Eagle Medium (DMEM) for $16 \mathrm{hr}$ at $37{ }^{\circ} \mathrm{C}$ and $5 \% \mathrm{CO}_{2}$. Then, cells were washed with fresh cell medium 
and treated with Compound 5, which was dissolved in PBS over a range of concentrations (as noted in the graph). After $3.5 \mathrm{hr}$ of incubation, the incubating medium was removed and cells were washed with PBS. Then, fresh DMEM medium $(80 \mu \mathrm{L})$ was added and followed by the addition of a $20 \mu \mathrm{L}$ of CellTiterBlue ${ }^{\circledR}$ reagent (Promega) after which the fluorescence of each well $\left(\lambda_{\text {ex }} / \lambda_{\text {em }}\right.$ of $573 \mathrm{~nm} / 584 \mathrm{~nm}$ ) was recorded using a dedicated plate reader. For each concentration of compound $\mathbf{5}$, the average fluorescence value was calculated from six biological replicates. Cells treated with $50 \%$ DMSO were used as a positive control.

\section{H. MRI experiments}

\section{Phantom Studies:}

Phantom experiments were performed on a 9.4 T wide-bore MR scanner (Bruker Avance system) at $37{ }^{\circ} \mathrm{C}$. A $25 \mathrm{~mm}$, double-resonant $\left({ }^{1} \mathrm{H} /{ }^{19} \mathrm{~F}\right)$ radiofrequency (RF) coil was used. Seven $5 \mathrm{~mm}$ NMR tubes containing $7 \mathrm{mM}$ of compound 5 without the addition of cations (blank) or with $100 \mu \mathrm{M}$ of either of the cations $\mathrm{Ca}^{2+}, \mathrm{Cu}^{2+}$, $\mathrm{Mg}^{2+}, \mathrm{Na}^{+}, \mathrm{K}^{+}$, and $\mathrm{Zn}^{2+}$ in $100 \mathrm{mM}$ Hepes buffer $(\mathrm{pH} \sim 7.4)$ were placed in a larger tube containing a $4 \%$ gelatin $(\mathrm{w} / \mathrm{w})$ solution in water. ${ }^{1} \mathrm{H}$ MRI: A RARE sequence was used to acquire ${ }^{1} \mathrm{H} \mathrm{MRI}$ images with the following parameters: $\mathrm{TR} / \mathrm{TE}=3000 / 42.4 \mathrm{~ms} ; \mathrm{FOV}=3.2 \times 3.2 \mathrm{~cm}$; matrix size=128 128; RARE factor=8; averages (NA=2). ${ }^{19} \mathrm{~F}$-iCEST MRI: A modified RAREst sequence at ${ }^{19} \mathrm{~F}-\mathrm{MRI}$ was used to perform the ${ }^{19} \mathrm{~F}$-iCESTMRI experiments with the following parameters: $\mathrm{TR} / \mathrm{TE}=6000 / 11 \mathrm{~ms}$; RARE factor $=16$; $8 \mathrm{~mm}$ slice; FOV=3.2 $\times 3.2 \mathrm{~cm}$; matrix size $=32 \times 32 ; \mathrm{NA}=100$, and a saturation pulse of $\mathrm{B}_{1}=2.5 \mu \mathrm{T}$ for $2 \mathrm{~s}$. The frequency of $B_{1}$ was swept from $\Delta \omega=+8 \mathrm{ppm}$ to $\Delta \omega=-8 \mathrm{ppm}$ in $150 \mathrm{~Hz}$ steps relative to the resonance of the $\mathbf{5}$ (set to $0 \mathrm{ppm}$ ). 


\section{In vivo MRI:}

Male C57BL/6 mice were purchased from Envigo (Israel). All the animal experiments were performed in accordance with the IACUC guidelines and regulations of the Weizmann Institute of Science. All animals survived the in vivo experiments with no observable undesired effects.

The following coordinates were used for intracranial implementation of the probe delivering cannula: For delivering $\mathbf{5}$ to the CA3 region of the hippocampus the cannula was located at the following coordinates (based on the mouse brain atlas): $2.42 \mathrm{~mm}(\mathrm{ML}), 2.15 \mathrm{~mm}(\mathrm{AP})$, and $2.00 \mathrm{~mm}$ (DV), relative to bregma. For delivering 5 to the thalamus $(\mathrm{TH})$ region the cannula was located at the following coordinates (based on the mouse brain atlas): $2.42 \mathrm{~mm}$ (ML), $2.15 \mathrm{~mm}$ (AP), and $3.50 \mathrm{~mm}$ (DV), relative to bregma. After successful cannula implantation at the location of interest in the animal brain, the animal was transferred to the Bruker BioSpec 15.2 Tesla AVANCE III HD imaging spectrometer equipped with a dual ${ }^{1} \mathrm{H} /{ }^{19} \mathrm{~F}, 23 \mathrm{~mm}$ RF coil. Compound 5 (10 mM at PBS) was the continuously infused (infusion rate was set to $0.25 \mu \mathrm{L} / \mathrm{min}$ ) and ${ }^{1} \mathrm{H}-\mathrm{MRI}$ followed by ${ }^{19} \mathrm{~F}$-iCEST data sets were aqcuired. $\quad{ }^{1} \mathrm{H}$ MRI: A RARE sequence was used to acquire the ${ }^{1} \mathrm{H} M R I$ images with the following parameters: TR/TE=5000/34.7 ms; FOV=2.2 $2.2 \mathrm{~cm}$; matrix size $=128 \times 128$; RARE factor=16, NA=2. Then, $90 \mathrm{~min}$ from starting the infusion of 5, a ${ }^{19} \mathrm{~F}-\mathrm{NMR}$ experiment was performed from which the frequency offset of the delivered $\mathbf{5}$ was determined as the center frequency offset $\left(\mathrm{O}_{1}\right)$ and ${ }^{19} \mathrm{~F}$-iCEST MRI data sets were acquired with the following parameters: A modified CEST-RAREst sequence, TR/TE=3000/10.9 ms; RARE factor $=16 ; 8 \mathrm{~mm}$ slice; $F O V=2.2 \times 2.2 \mathrm{~cm}$; matrix size $=32 \times 32 ; \mathrm{NA}=400$; and a saturation pulse $\mathrm{B}_{1}=2 \mu \mathrm{T}$ for $1.5 \mathrm{~s}$. Four data sets were acquired with the parameters mentioned above with two at which $B_{1}$ was applied "on resonance" $(\Delta \omega=+3.2 \mathrm{ppm})$ and another two at which $\mathrm{B}_{1}$ was applied "off resonance" ( $\Delta \omega=-3.2 \mathrm{ppm}$ ). These data sets were acquired in alternate order and were averaged out separately. To obtain the ${ }^{19} \mathrm{~F}$-iCEST MRI contrast, averaged "on resonance" images were subtracted from averaged "off resonance" images. One set of experiments was applied on a group of mice $(\mathrm{N}=7)$ implanted 
with a cannula at the CA3 region where $\Delta \omega$ was applied at either +18 ppm or -18 ppm and that data was processed in a similar way to the described above.

\section{Supporting Information Figures:}

a.

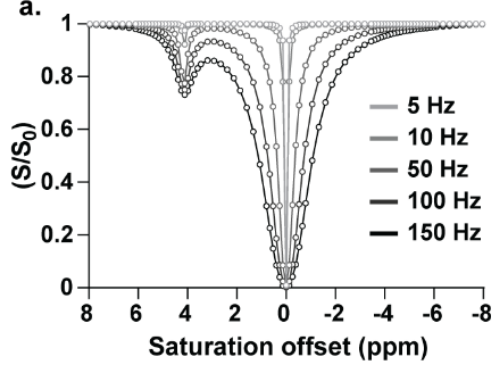

b.

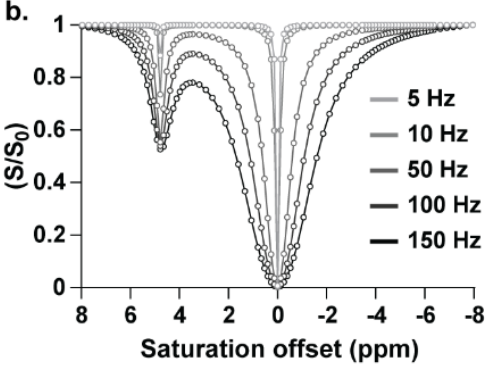

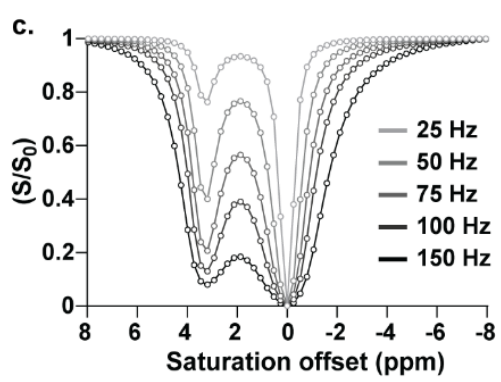

Figure S1: Experimental z-spectra of multi power ${ }^{19} \mathrm{~F}$-iCEST experiments for compound 3,4,5 with $\mathrm{Zn}^{2+}$. a) $3 \mathrm{mM}$ of compound 3 and $120 \mu \mathrm{M}$ of $\mathrm{Zn}^{2+}$. b) $3 \mathrm{mM}$ of compound 4 and $30 \mu \mathrm{M}$ of $\mathrm{Zn}^{2+}$. c) $3 \mathrm{mM}$ of compound 5 and $40 \mu \mathrm{M}$ of $\mathrm{Zn}^{2+}$. All the solutions were prepared in $100 \mathrm{mM}$ Hepes buffer $(\mathrm{pH} \sim 7.4)$ and ${ }^{19} \mathrm{~F}-\mathrm{iCEST}$ experiments was performed on $9.4 \mathrm{~T} \mathrm{NMR}$ at $37^{\circ} \mathrm{C}$.

Table S1: Dissociation constant $\left(K_{d}\right)$ determination by ${ }^{19} \mathrm{~F}-\mathrm{NMR} . K_{d}\left[5-\mathrm{Zn}^{2+}\right]=5.5 \pm 0.6 \times 10^{-3} \mathrm{M}$.

\begin{tabular}{|c|c|c|c|c|}
\hline $\begin{array}{c}\text { Prepared solution } \\
\left(\text { ratio of } \mathrm{Zn}^{2+}: \mathbf{5}\right)\end{array}$ & $\begin{array}{c}\text { Compound 5 } \\
{[\mathrm{mM}]}\end{array}$ & $\begin{array}{c}\mathrm{Zn}^{2+} \\
{[\mathrm{mM}]}\end{array}$ & $\begin{array}{c}{[\mathbf{5}-\mathrm{Zn}] /[\mathbf{5}]} \\
(\text { NMR integrals })\end{array}$ & $\begin{array}{c}K_{d} \\
{\left[\times 10^{-3} \mathrm{M}\right]}\end{array}$ \\
\hline $1: 0.5$ & 1 & 2 & 0.32 & 5.506 \\
\hline $1: 0.45$ & 1 & 2.222 & 0.314 & 6.307 \\
\hline $1: 0.4$ & 1 & 2.5 & 0.424 & 5.187 \\
\hline $1: 0.35$ & 1 & 2.85 & 0.452 & 5.6 \\
\hline $1: 0.3$ & 1 & 3.3333 & 0.655 & 4.47 \\
\hline $1: 0.2$ & 1 & 5 & 0.759 & 6.00 \\
\hline
\end{tabular}




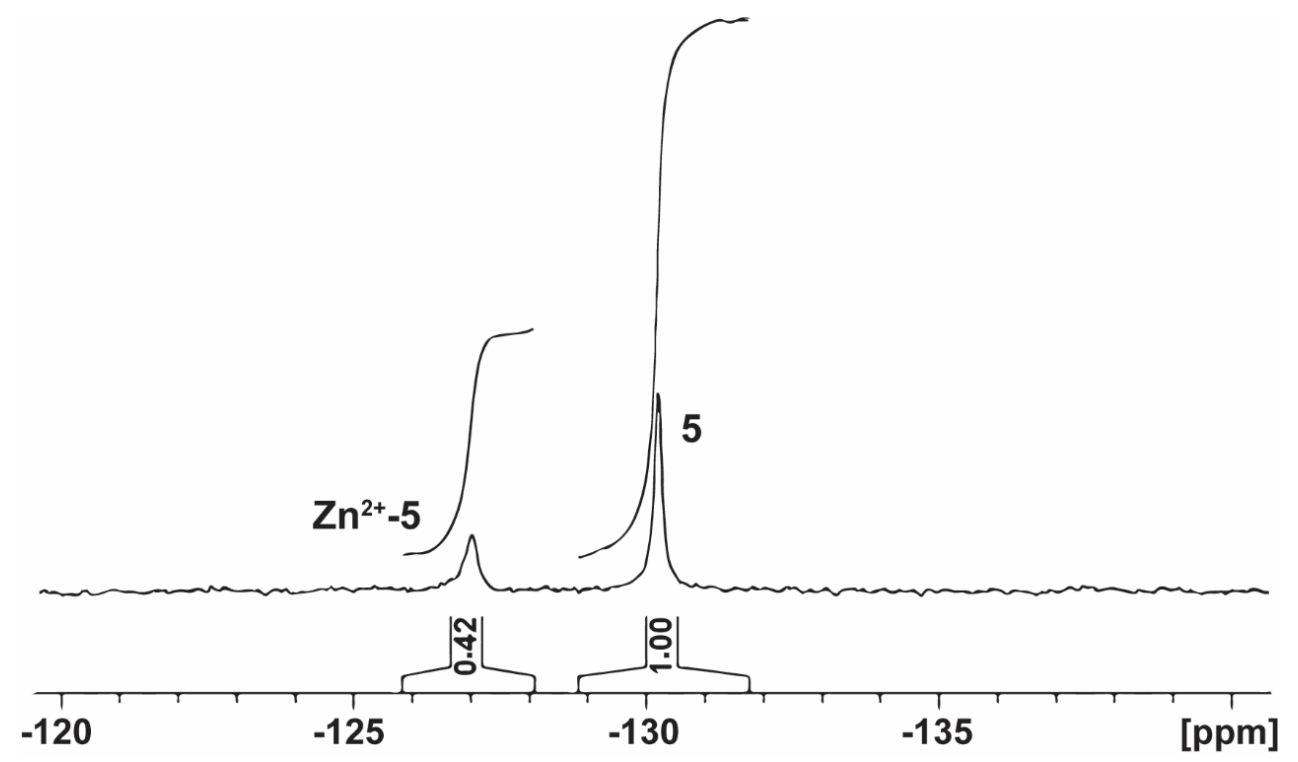

Figure S2: ${ }^{19} \mathrm{~F}-\mathrm{NMR}$ for $\boldsymbol{K}_{\boldsymbol{d}}$ determination: Representative ${ }^{19} \mathrm{~F}-\mathrm{NMR}$ spectrum of solution prepared with 5: $\mathrm{Zn}^{2+}$ ration of 1:0.4 (in $100 \mathrm{mM}$ Hepes buffer, $\mathrm{pH} \sim 7.4$ at $25^{\circ} \mathrm{C}$ on $11.7 \mathrm{~T}$ NMR spectrometer). The noted integration values were used to calculate the dissociation constant $\left(K_{d}\right)$.
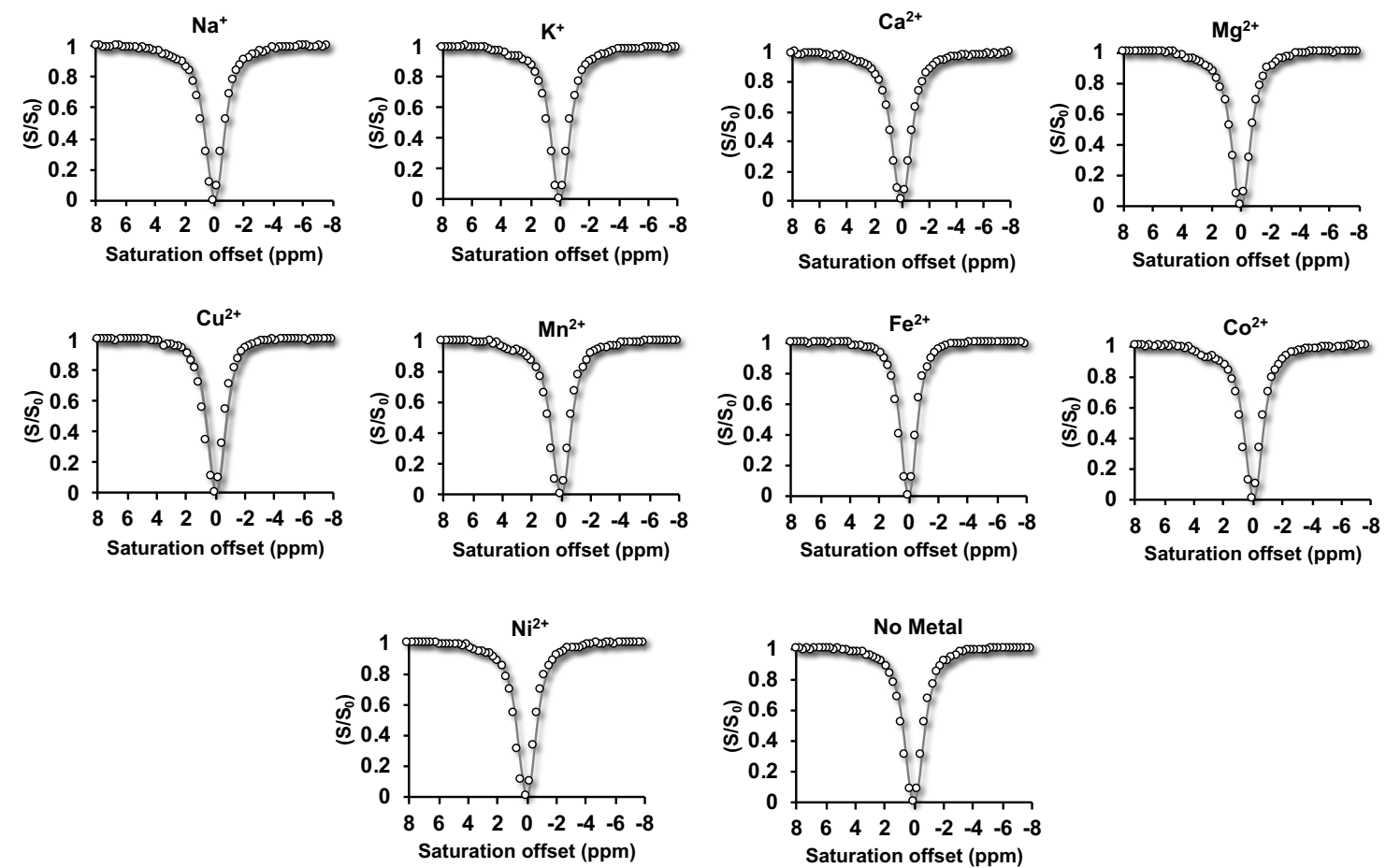

Figure S3: ${ }^{19} \mathrm{~F}$-iCEST spectra of $3 \mathrm{mM}$ of compound 5 in presence of $30 \mu \mathrm{M}$ of $\left(\mathrm{Na}^{+}, \mathrm{K}^{+}, \mathrm{Mg}^{2+}, \mathrm{Ca}^{2+}, \mathrm{Mn}^{2+}\right.$, $\mathrm{Fe}^{2+}, \mathrm{Co}^{2+}, \mathrm{Ni}^{2+}, \mathrm{Cu}^{2+}$, no metal) in $100 \mathrm{mM}$ Hepes buffer $(\mathrm{pH} 7.2)$ at $37^{\circ} \mathrm{C}$. 


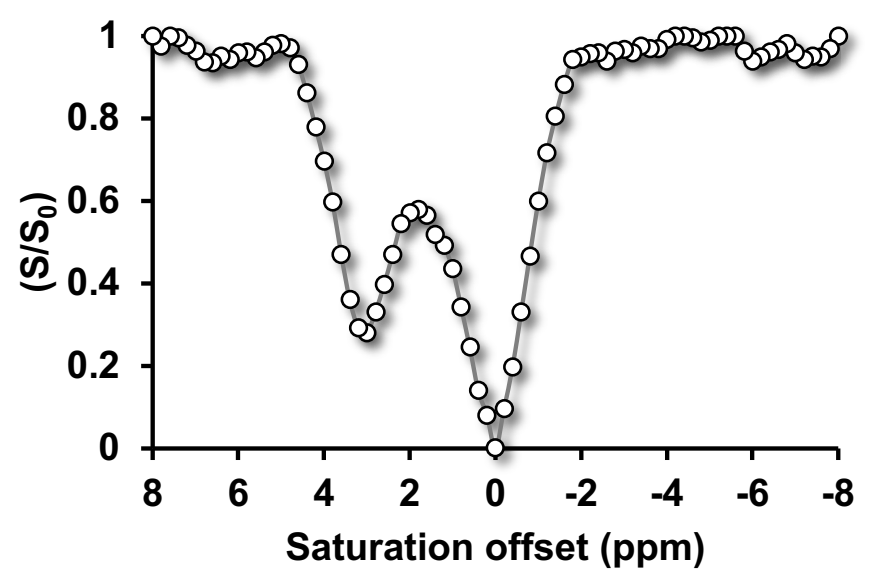

Figure S4: ${ }^{19} \mathrm{~F}$-iCEST MRI Z-spectrum of phantom tube containing $\mathbf{Z n}^{2+}: 7 \mathrm{mM}$ of compound $\mathbf{5}$ and 100 $\mu \mathrm{M}$ of $\mathrm{Zn}^{2+}$ was dissolved in $100 \mathrm{mM}$ Hepes buffer $(\mathrm{pH}=7.4)$ and ${ }^{19} \mathrm{~F}$-iCEST MRI experiment was performed on 9.4 T wide-bore MR scanner.

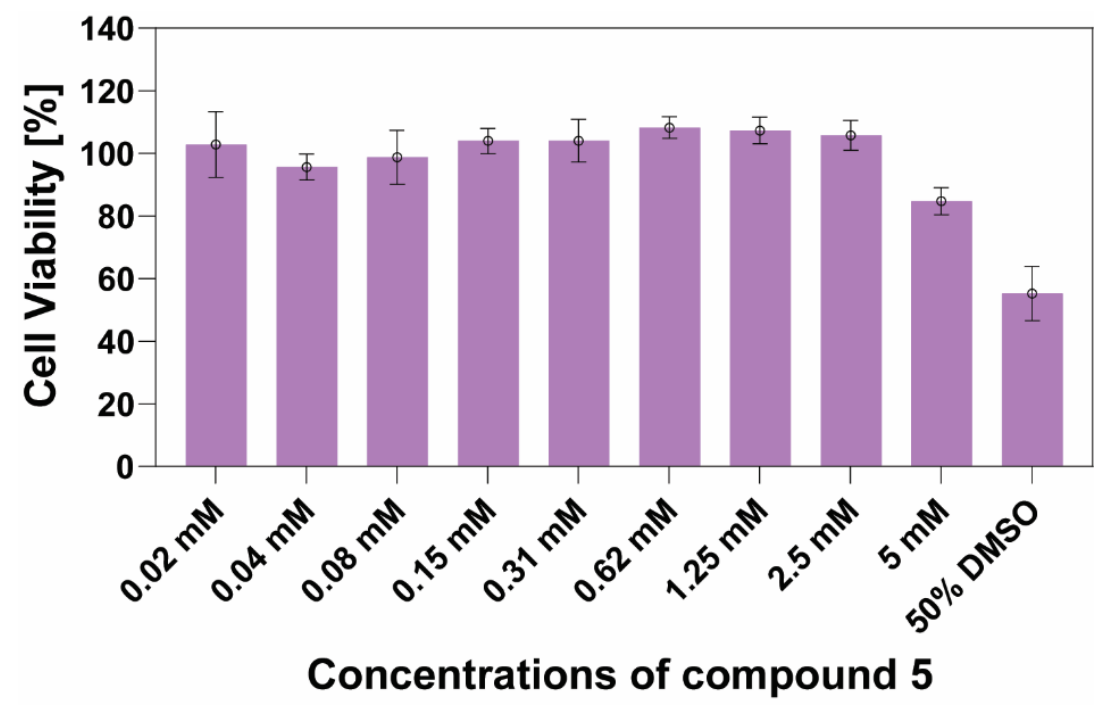

Figure S5: Cell Titer-Blue assay: Concentration-response bar-graph of cell Titer-Blue assay performed on $\mathrm{CHO}$ cells representing cell viability as a function of the concentration of compound $\mathbf{5}$ in the medium. Cells were incubated with the shown concentration for $3.5 \mathrm{~h}$ at $37{ }^{\circ} \mathrm{C}$. Treatment with $50 \%$ DMSO was used as a positive control. The data is shown as the percentile of live cells (relative to untreated cells) and expressed as mean \pm SD of six repetitions. 


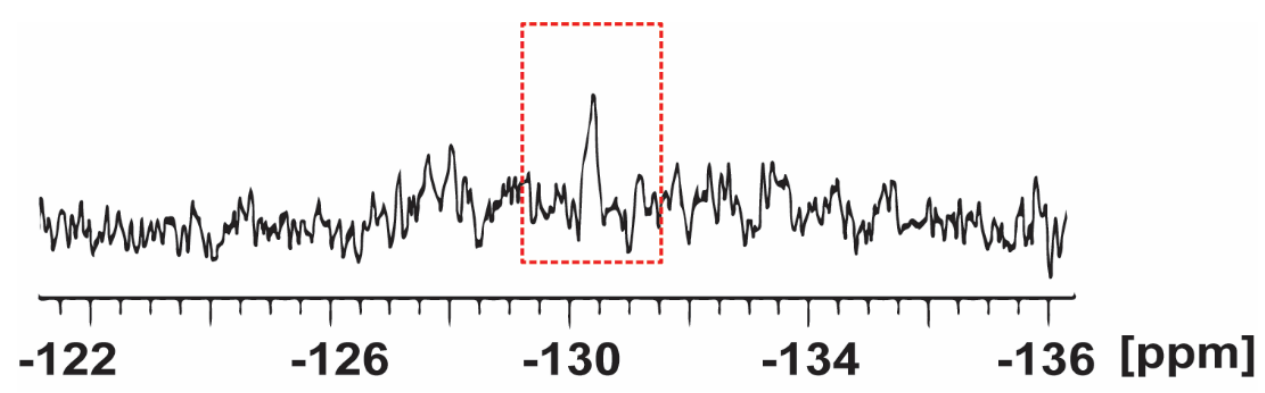

Figure S6: ${ }^{19} \mathrm{~F}$ NMR of cells: Cells were incubated with $2 \mathrm{mM}$ of compound $\mathbf{5}$ for $3.5 \mathrm{~h}$ and ${ }^{19} \mathrm{~F}$ NMR was performed on 9.4 T NMR to check whether compound 5 enters the cells or not.

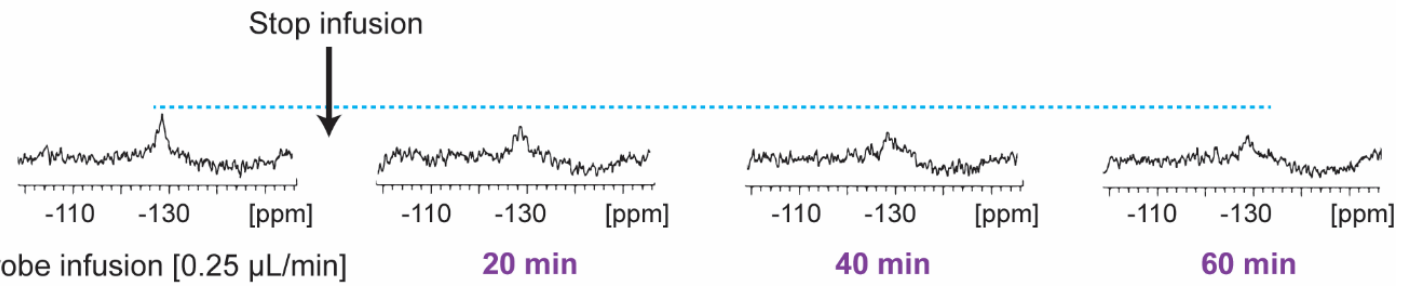

Figure S7: Washout studies of 5 in vivo: ${ }^{19} \mathrm{~F}-\mathrm{NMR}$ spectrum (left) obtained from a mouse brain following 90 min of 5 infusion ( $10 \mathrm{mM}$ in PBS, $0.25 \mu \mathrm{L} / \mathrm{min}$ rate). The black arrow shows the time at which the infusion of 5 was stopped. Then a set of ${ }^{19} \mathrm{~F}-\mathrm{NMR}$ spectra were acquired 20, 40 and $60 \mathrm{~min}$ after stopping the delivery of 5 representing the probe washout from the tissue ( ${ }^{19} \mathrm{~F}-$ signal drops over time).

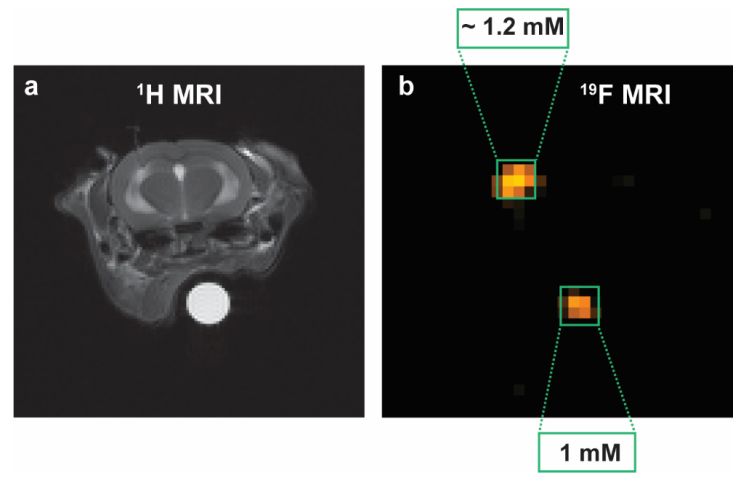

Figure S8: Estimation of the concentration of 5 in the mouse brain: Ninety minutes after starting the infusion of $\mathbf{5}(10 \mathrm{mM}$ in PBS, $0.25 \mu \mathrm{L} / \mathrm{min}$ rate $)$ its concentration was estimated using the ${ }^{19} \mathrm{~F}-\mathrm{MRI}$ signal of a reference tube that contained $1 \mathrm{mM}$ of 5 in PBS. a. ${ }^{1} \mathrm{H}$ MRI (matrix size $128 \times 128$ ), b. ${ }^{19} \mathrm{~F}$ MRI (matrix size 32 $\times 32$ ). From the obtained ${ }^{19} \mathrm{~F}-\mathrm{MRI}$ the concentration of 5 in the brain was determined to be $1.2 \mathrm{mM}$. 

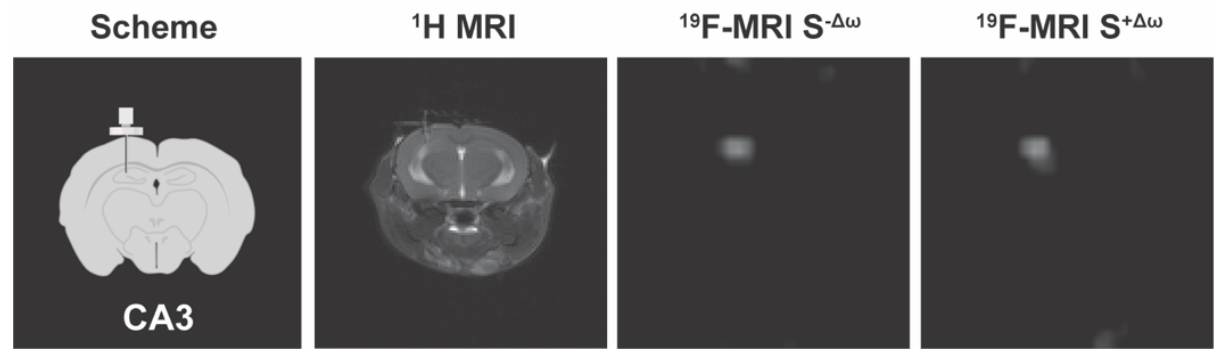

${ }^{19} \mathrm{~F}-\mathrm{iCEST}$

Figure S9: In vivo ${ }^{19} \mathrm{~F}$-iCEST maps in live animal brain at $18 \mathrm{ppm}$. Continuous delivery of $10 \mathrm{mM}$ compound 5 to CA3 in hippocampal region of brain via implanted cannula, ${ }^{1} \mathrm{H} \mathrm{MRI},{ }^{19} \mathrm{~F}$-iCEST at $\Delta \omega=-18 \mathrm{ppm},{ }^{19} \mathrm{~F}-$ iCEST at $\Delta \omega=+18 \mathrm{ppm},{ }^{19} \mathrm{~F}$-iCEST contrast overlaid on ${ }^{1} \mathrm{H}$ MRI. The infusion rate of 5 was set to $0.25 \mu \mathrm{L} / \mathrm{min}$ and iCEST data acquisition started 90 min from starting the infusion of 5.

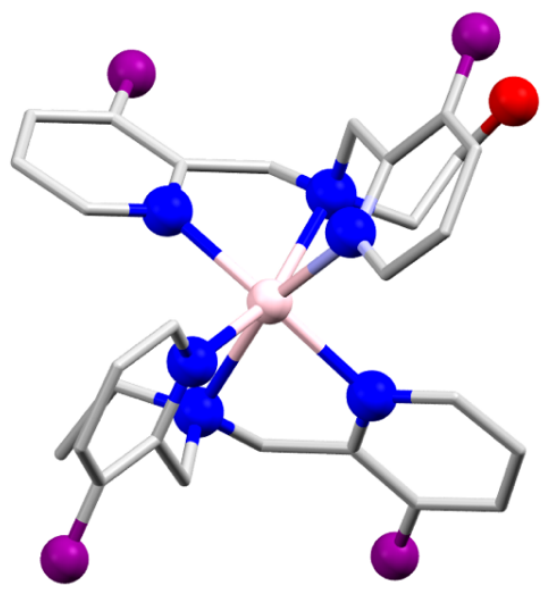

Figure S10: Crystal structure of compound $2+\mathrm{Zn}^{2+}$.

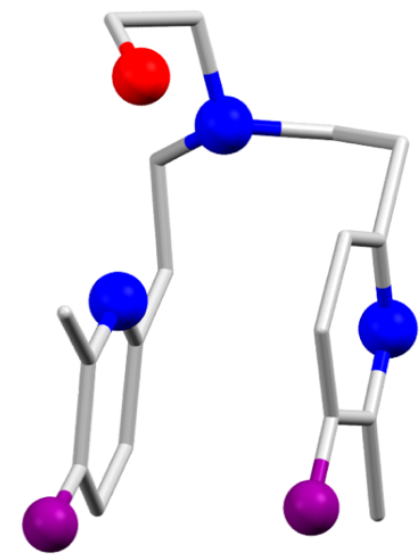

Figure S11: Crystal structure of compound 6. 


\section{J. NMR $\left({ }^{1} \mathrm{H},{ }^{13} \mathrm{C},{ }^{19} \mathrm{~F}\right)$ \& HRMS Spectra}

\section{Compound $1\left({ }^{1} \mathrm{H},{ }^{13} \mathrm{C},{ }^{19} \mathrm{~F}, \mathrm{HRMS}\right)$}

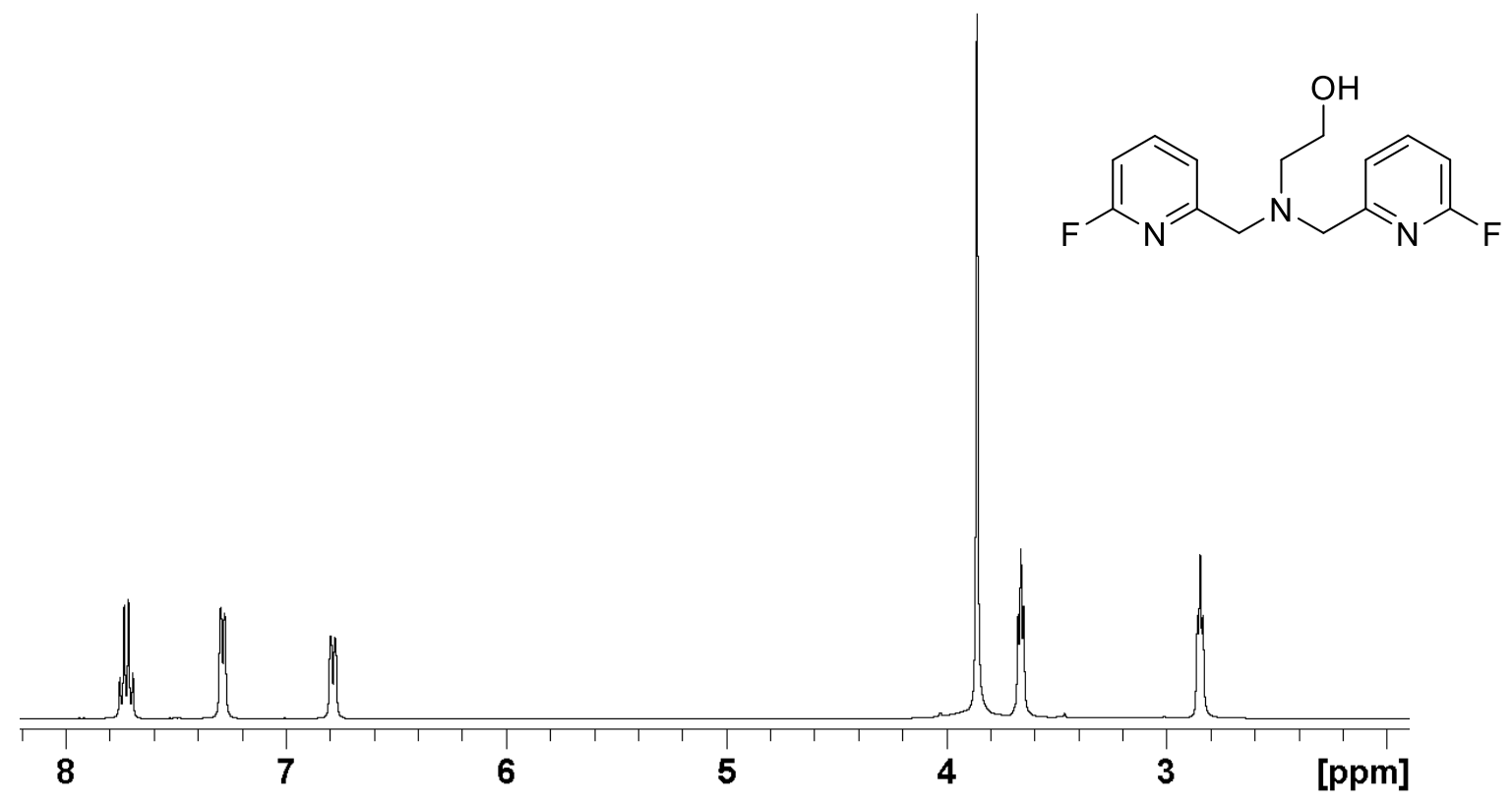

Figure S12: ${ }^{1} \mathrm{H}$ NMR $\left(400.35 \mathrm{MHz}, \mathrm{CDCl}_{3}, 25^{\circ} \mathrm{C}\right)$ spectrum of compound 1.

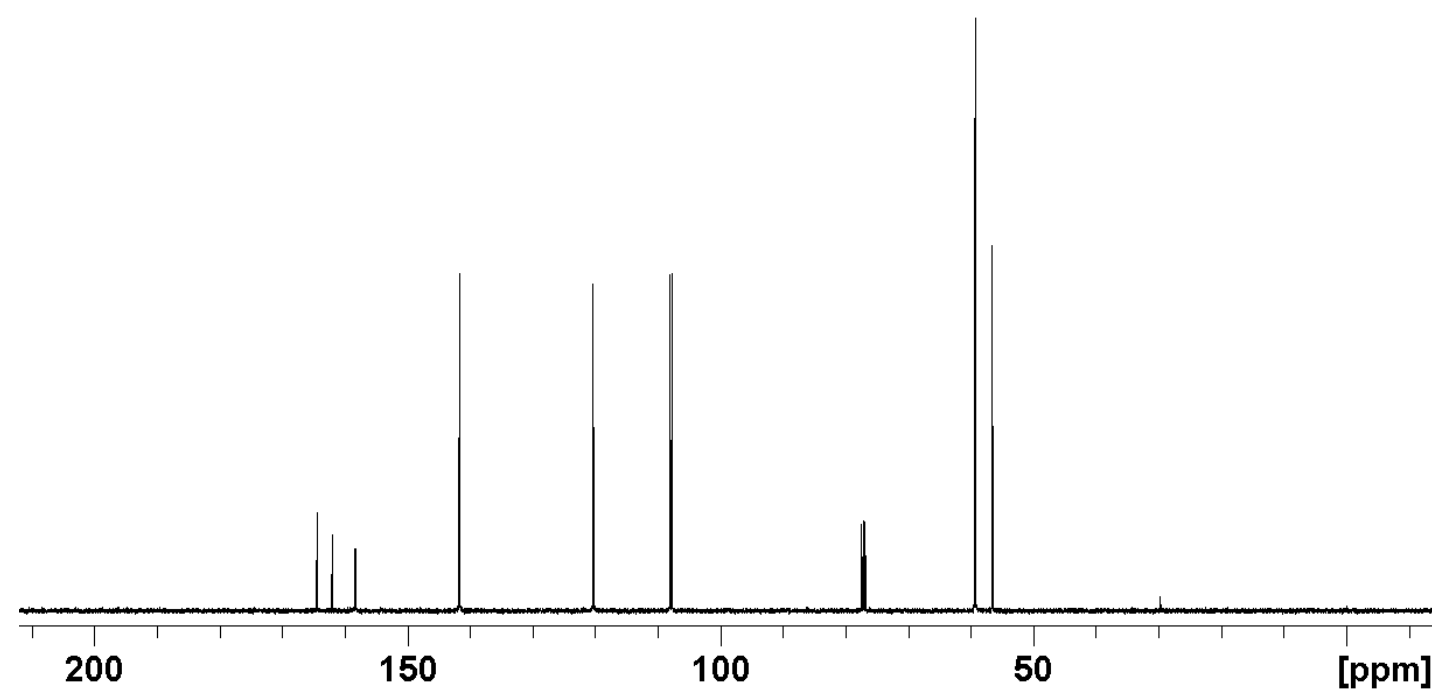

Figure S13: ${ }^{13} \mathrm{C}\left\{{ }^{1} \mathrm{H}\right\} \mathrm{NMR}\left(100.67 \mathrm{MHz}, \mathrm{CDCl}_{3}, 25^{\circ} \mathrm{C}\right)$ spectrum of compound 1. 


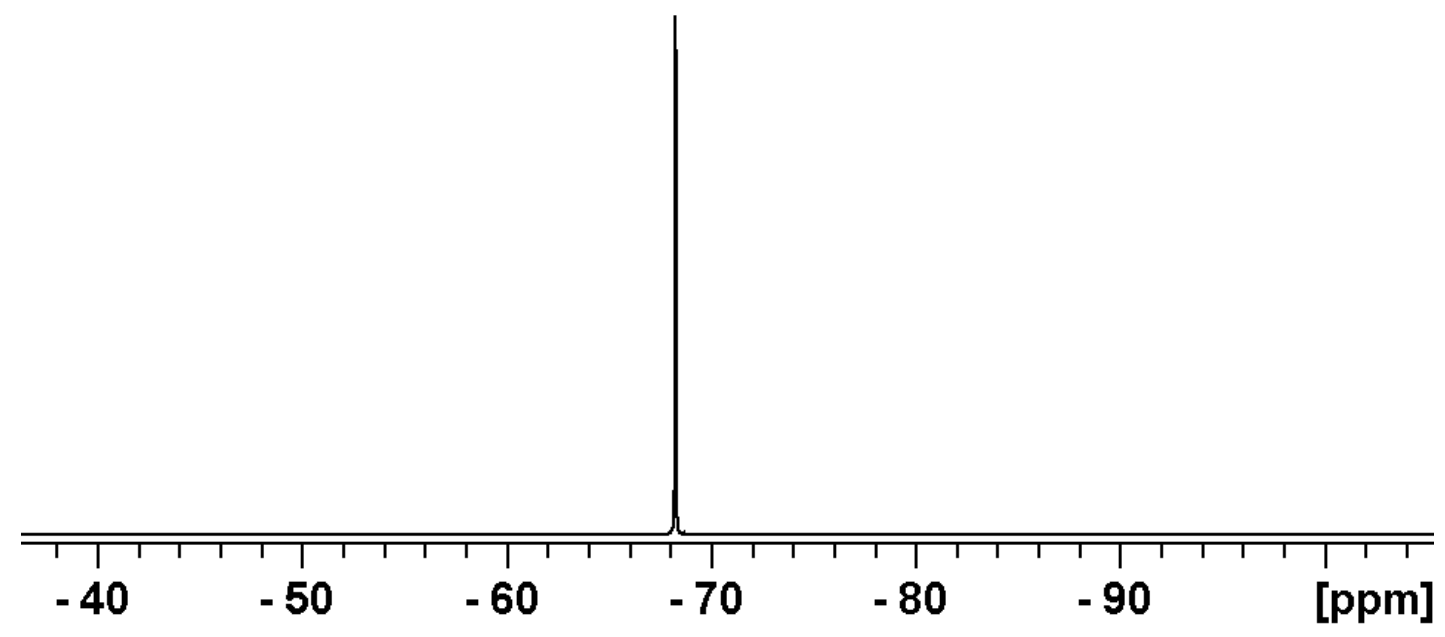

Figure S14: ${ }^{19} \mathrm{~F} \mathrm{NMR}\left(376.7 \mathrm{MHz}, \mathrm{CDCl}_{3}, 25^{\circ} \mathrm{C}\right)$ spectrum of compound 1.

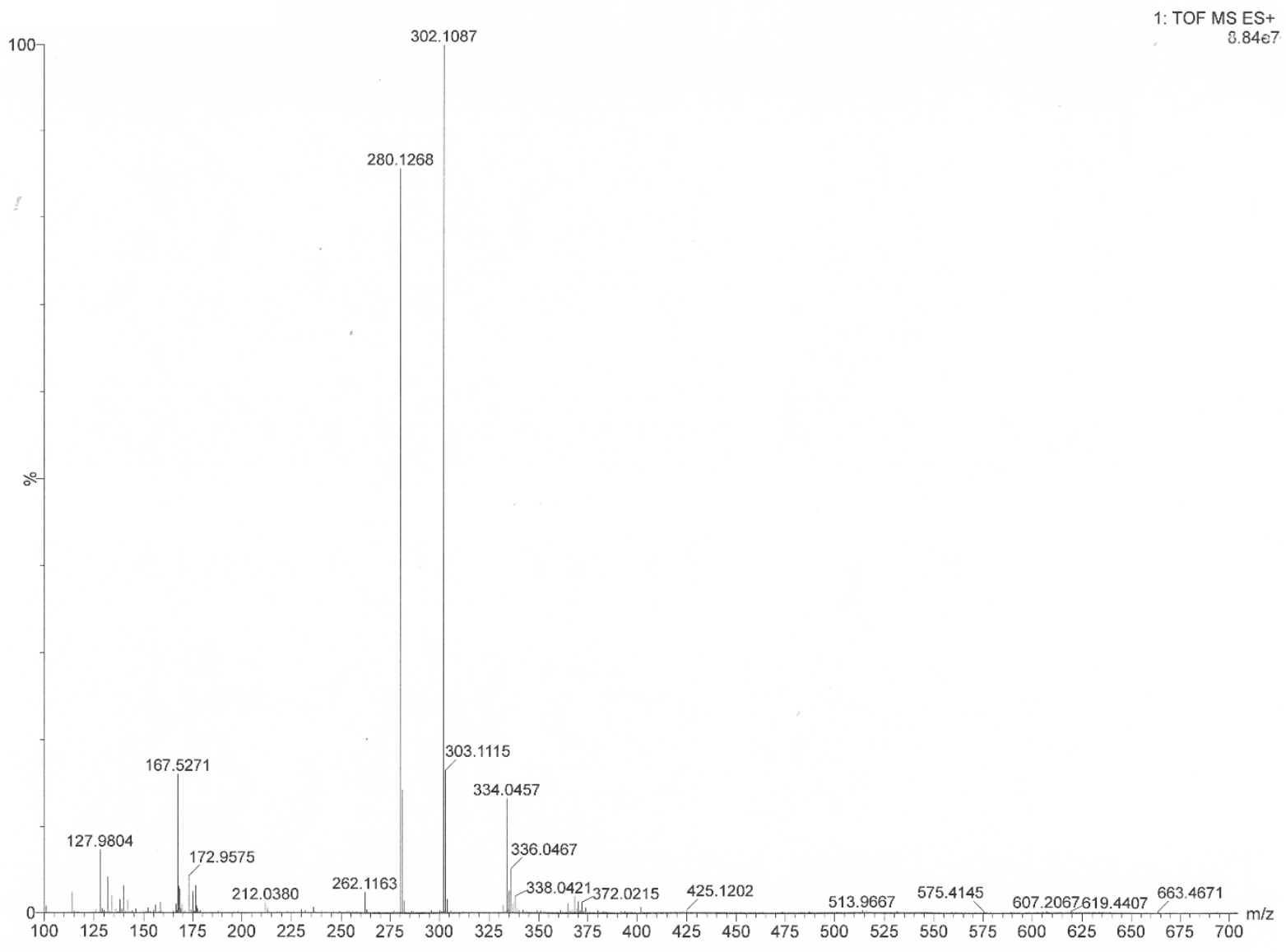

Figure S15: HRMS (ESI) spectrum of compound 1. 
Compound $2\left({ }^{1} \mathrm{H},{ }^{13} \mathrm{C},{ }^{19} \mathrm{~F}, \mathrm{HRMS}\right)$

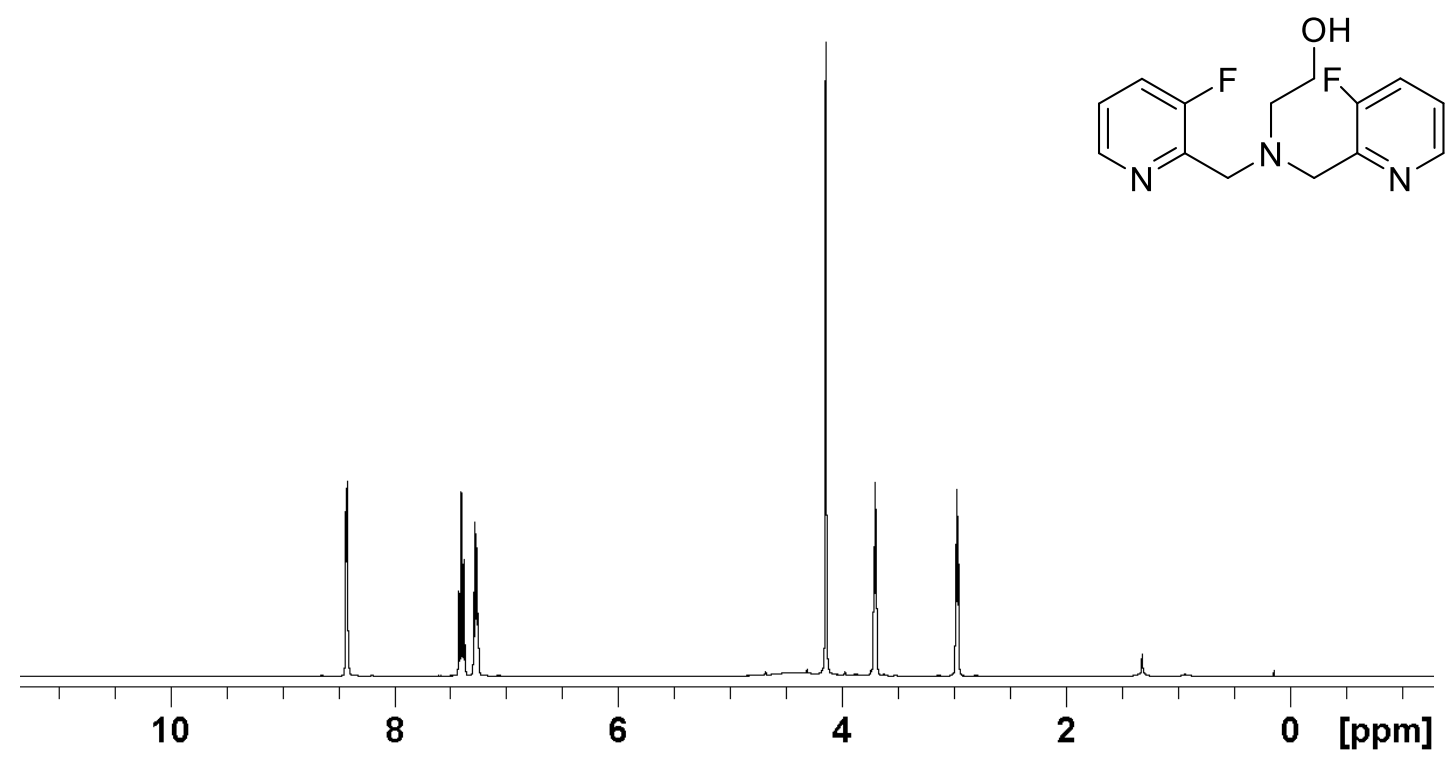

Figure S16: ${ }^{1} \mathrm{H}$ NMR $\left(400.35 \mathrm{MHz}, \mathrm{CDCl}_{3}, 25^{\circ} \mathrm{C}\right)$ spectrum of compound 2.

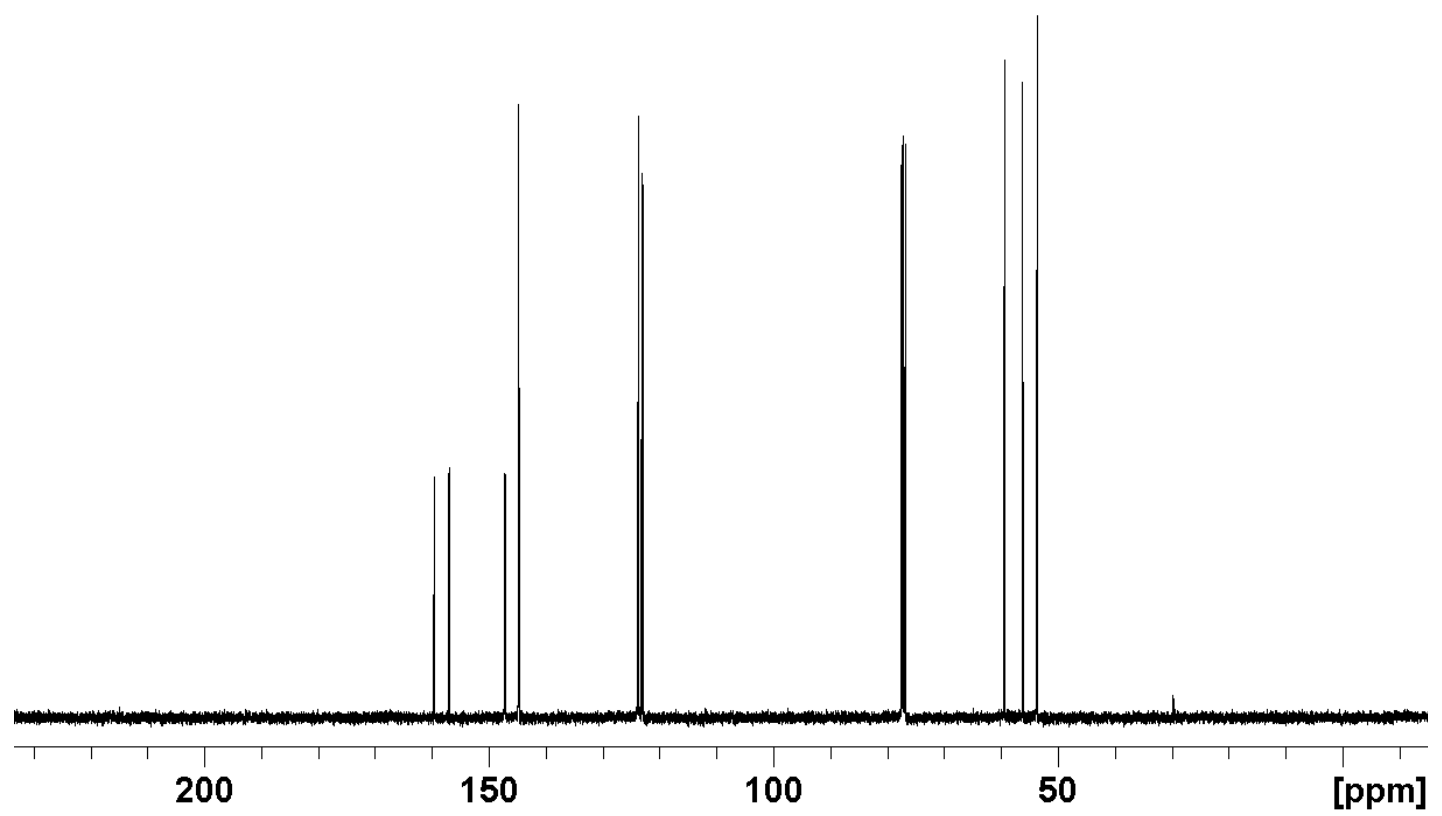

Figure S17: ${ }^{13} \mathrm{C}\left\{{ }^{1} \mathrm{H}\right\}$ NMR $\left(100.67 \mathrm{MHz}, \mathrm{CDCl}_{3}, 25^{\circ} \mathrm{C}\right)$ spectrum of compound 2. 


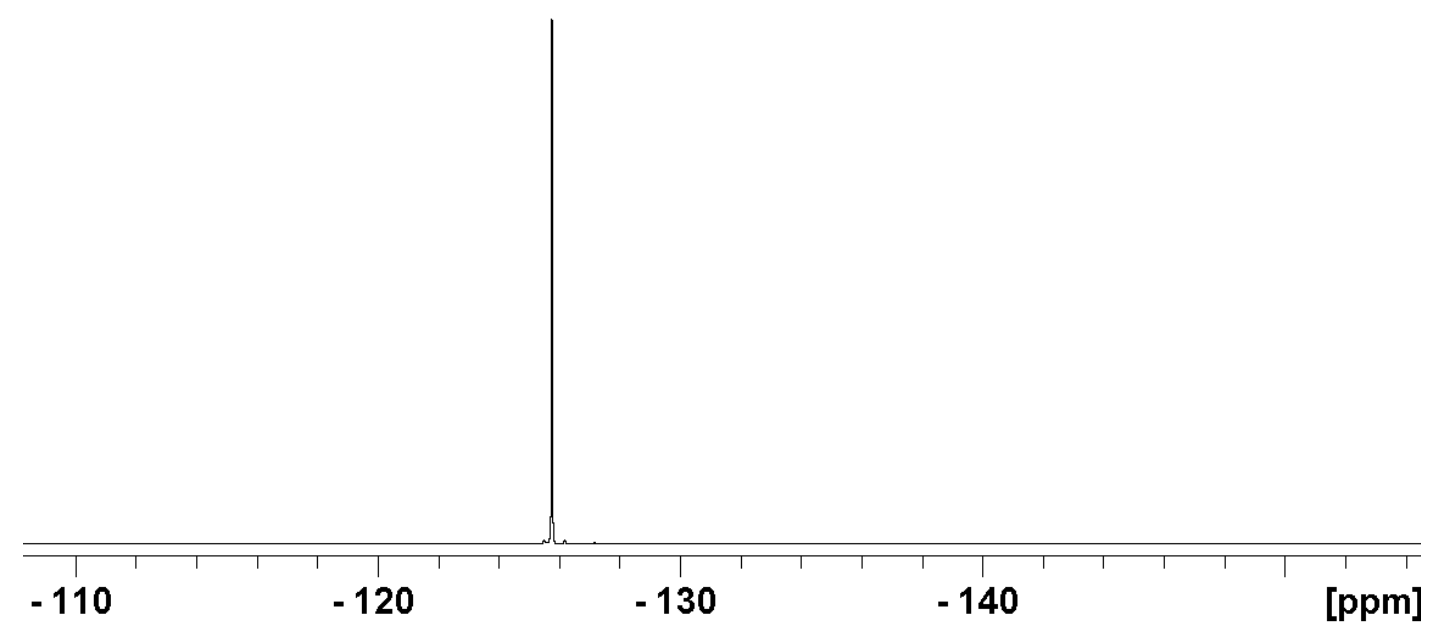

Figure S18: ${ }^{19} \mathrm{~F} \mathrm{NMR}\left(376.7 \mathrm{MHz}, \mathrm{CDCl}_{3}, 25^{\circ} \mathrm{C}\right)$ spectrum of compound 2.

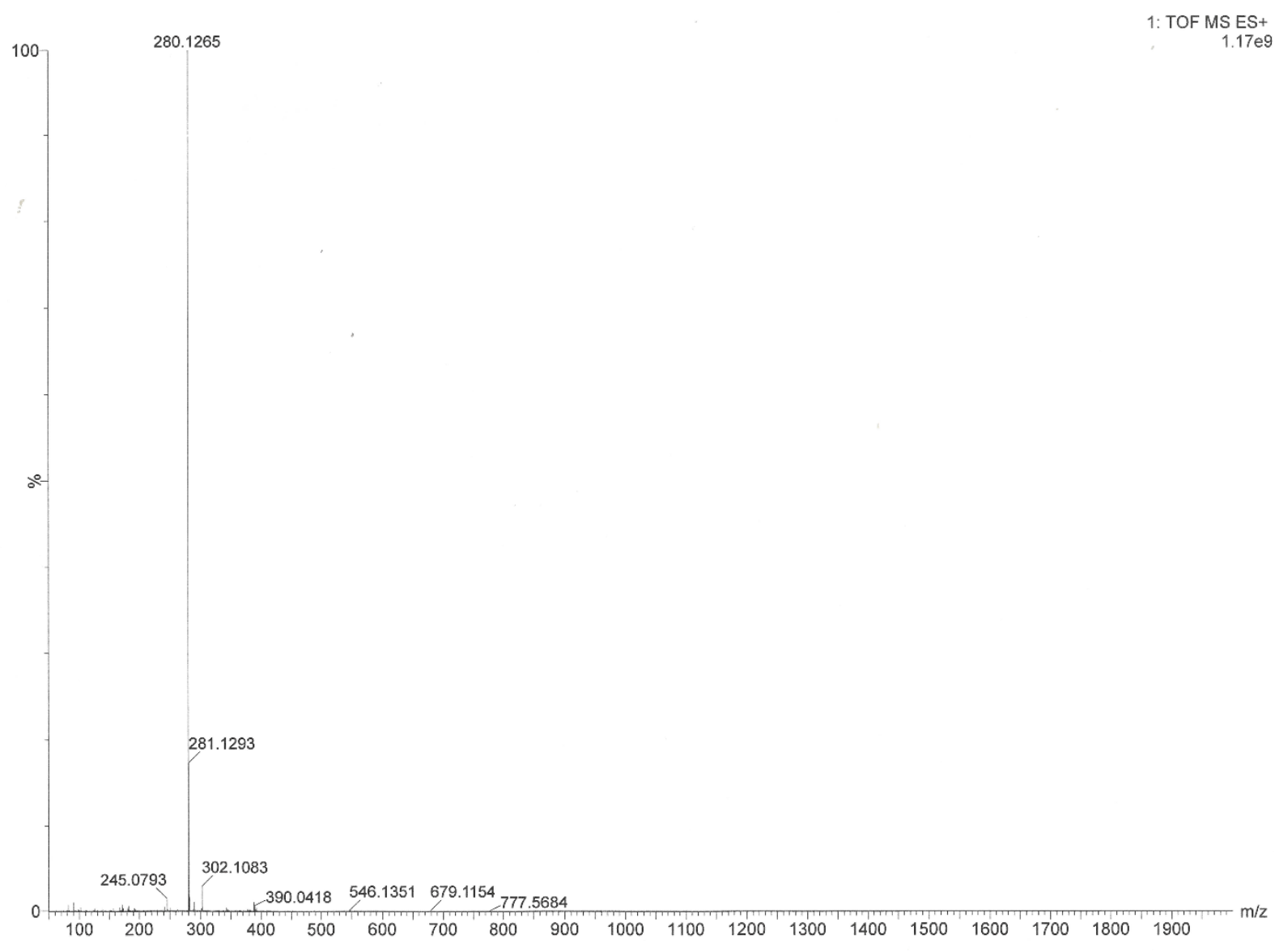

Figure S19: HRMS (ESI) spectrum of compound 2. 
Compound $3\left({ }^{1} \mathrm{H},{ }^{13} \mathrm{C},{ }^{19} \mathrm{~F}, \mathrm{HRMS}\right)$

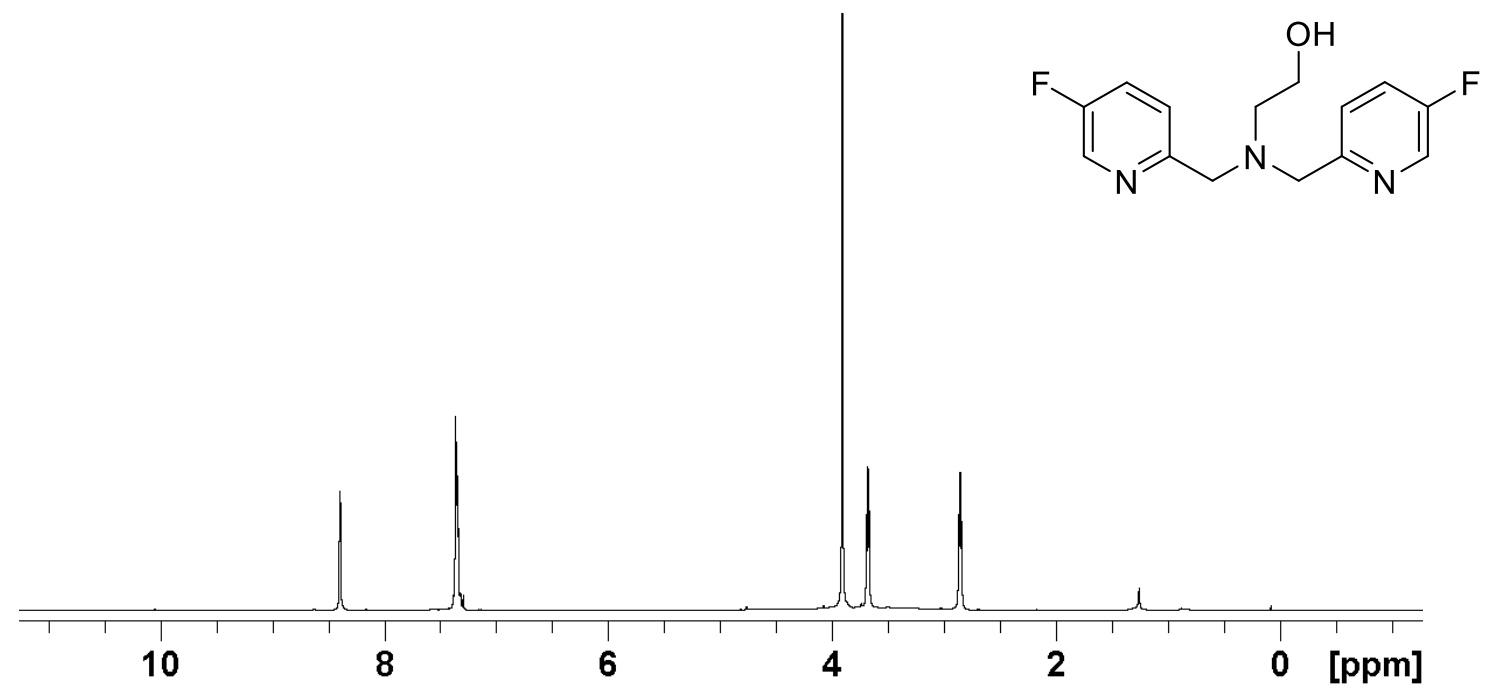

Figure S20: ${ }^{1} \mathrm{H}$ NMR $\left(400.35 \mathrm{MHz}, \mathrm{CDCl}_{3}, 25^{\circ} \mathrm{C}\right)$ spectrum of compound 3 .

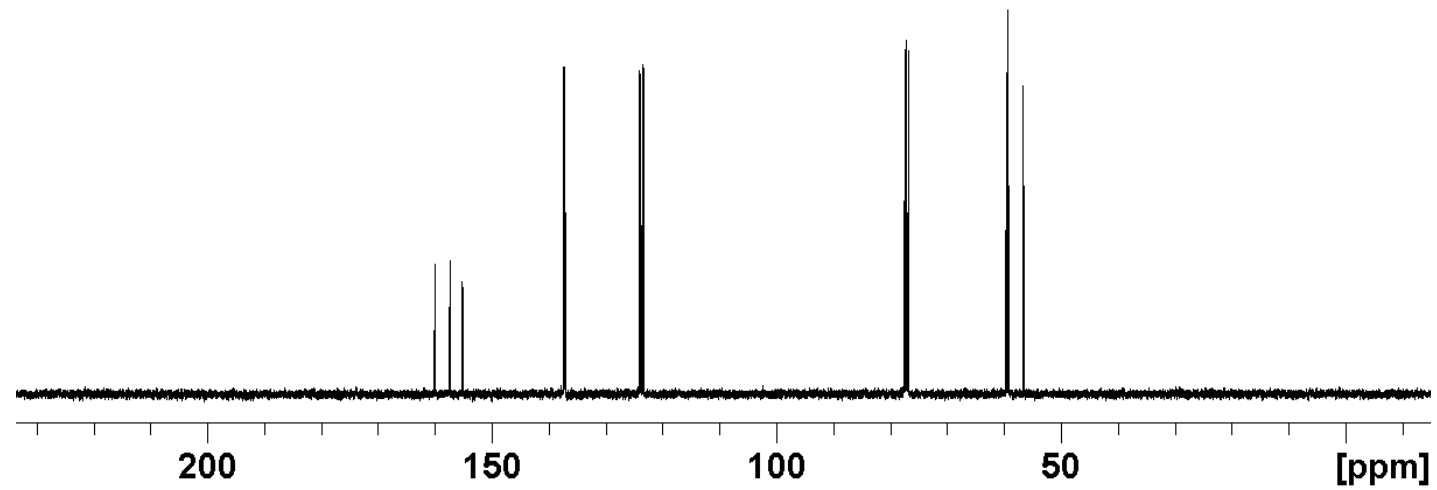

Figure S21: ${ }^{13} \mathrm{C}\left\{{ }^{1} \mathrm{H}\right\}$ NMR $\left(100.67 \mathrm{MHz}, \mathrm{CDCl}_{3}, 25^{\circ} \mathrm{C}\right)$ spectrum of compound 3 . 


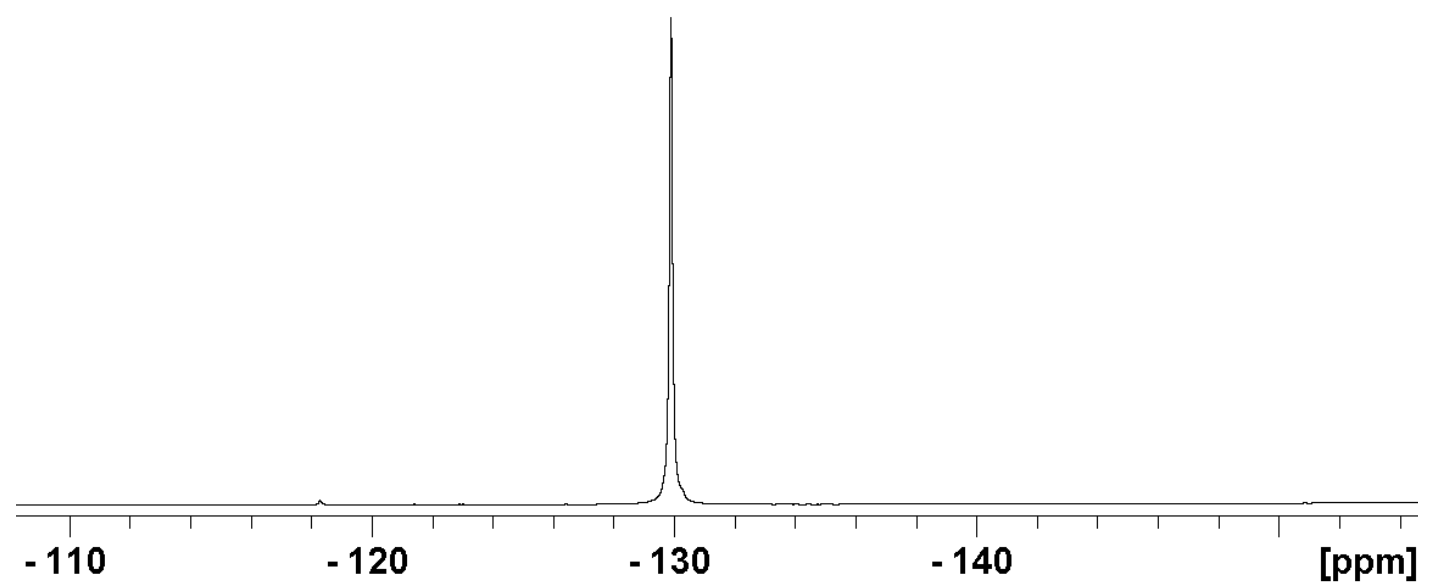

Figure S22: ${ }^{19} \mathrm{~F}$ NMR $\left(376.7 \mathrm{MHz}, \mathrm{CDCl}_{3}, 25^{\circ} \mathrm{C}\right)$ spectrum of compound 3.

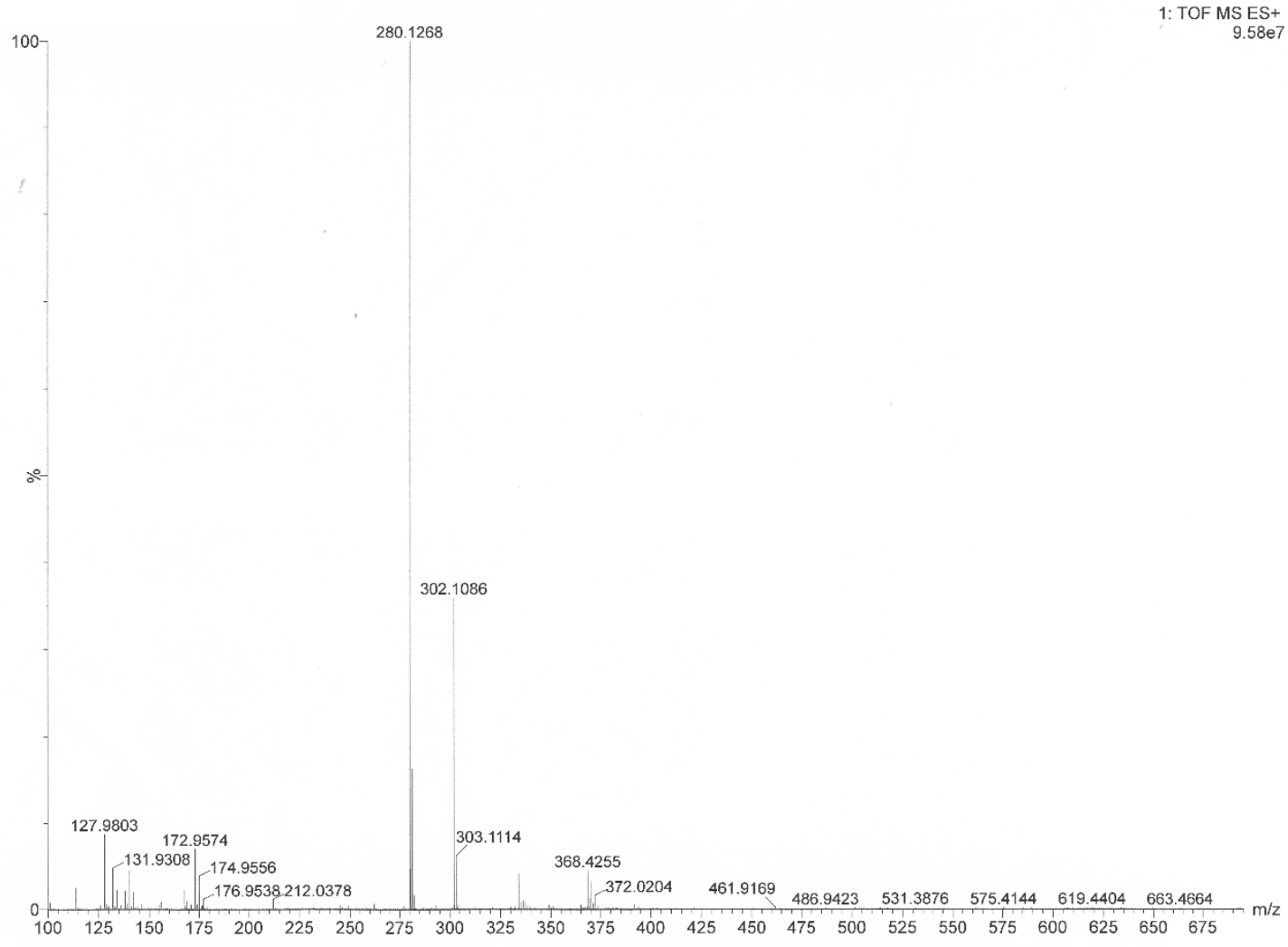

Figure S23: HRMS (ESI) spectrum of compound 3. 
Compound $4\left({ }^{1} \mathrm{H},{ }^{13} \mathrm{C},{ }^{19} \mathrm{~F}, \mathrm{HRMS}\right)$

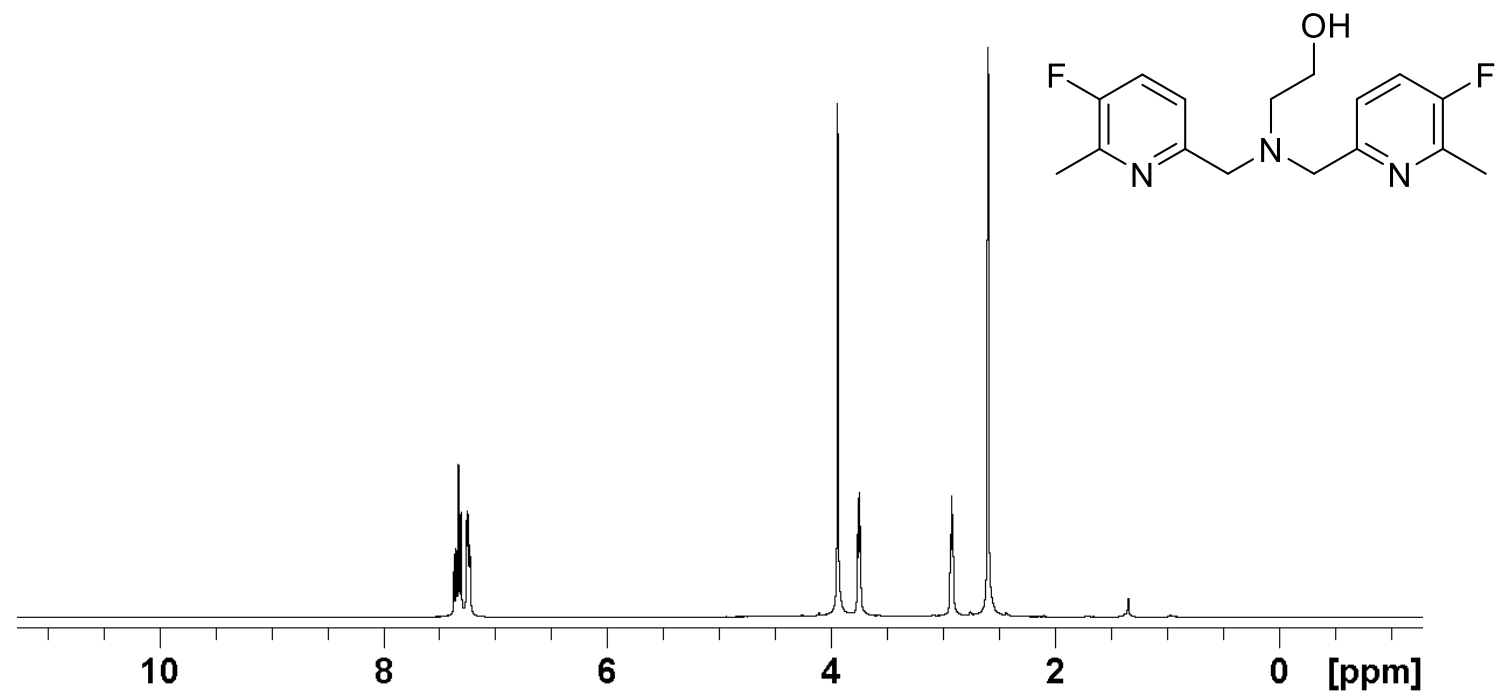

Figure S24: ${ }^{1} \mathrm{H}$ NMR $\left(400.35 \mathrm{MHz}, \mathrm{CDCl}_{3}, 25^{\circ} \mathrm{C}\right)$ spectrum of compound 4 .

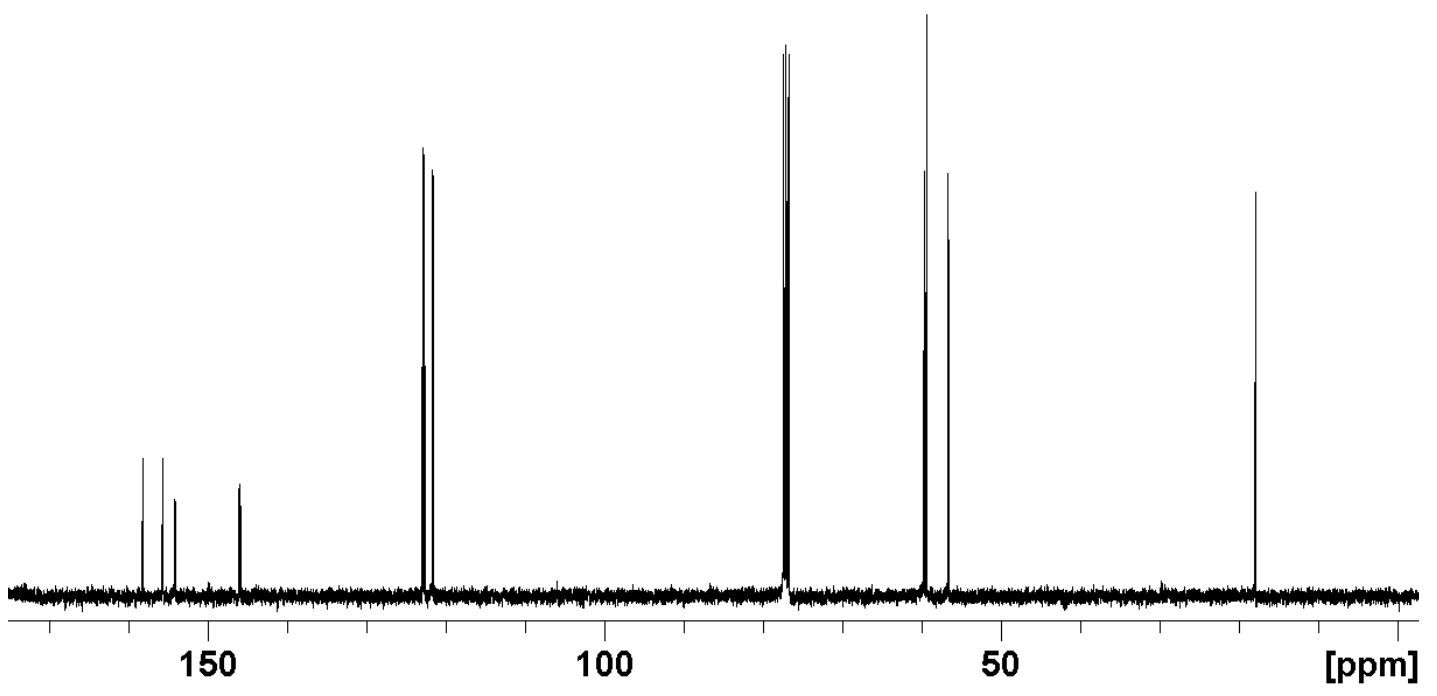

Figure S25: ${ }^{13} \mathrm{C}\left\{{ }^{1} \mathrm{H}\right\} \mathrm{NMR}\left(100.67 \mathrm{MHz}, \mathrm{CDCl}_{3}, 25^{\circ} \mathrm{C}\right)$ spectrum of compound 4. 


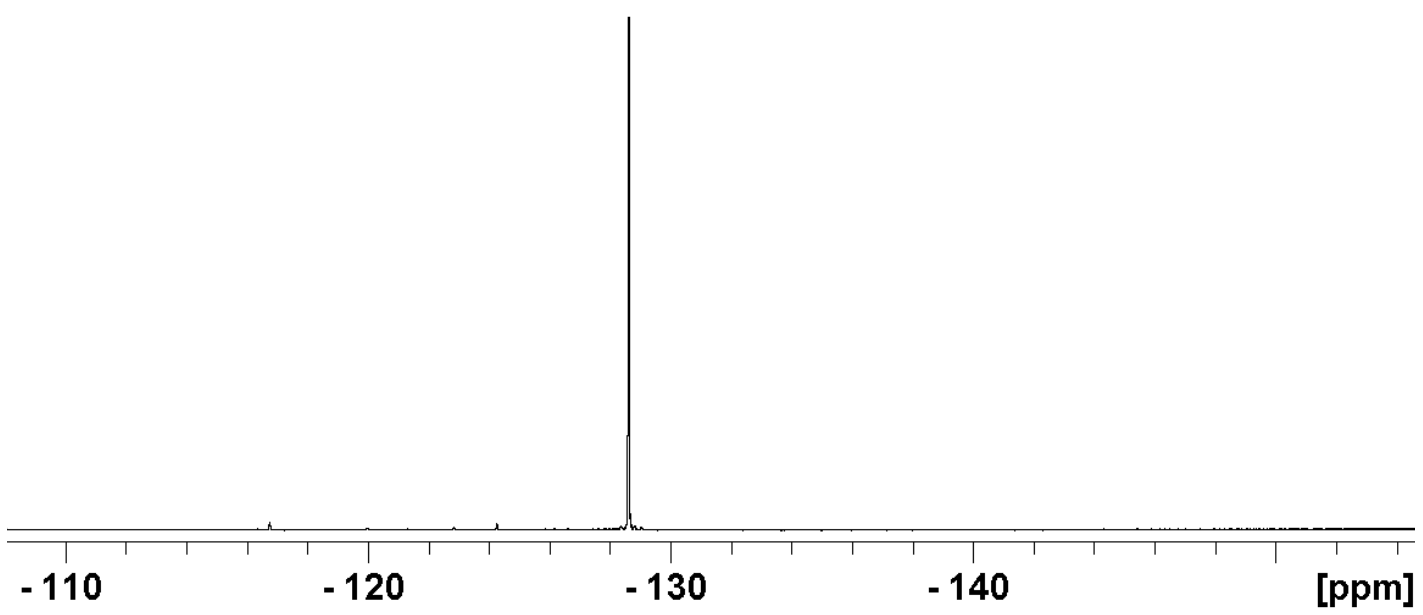

Figure S26: ${ }^{19} \mathrm{~F} \mathrm{NMR}\left(376.7 \mathrm{MHz}, \mathrm{CDCl}_{3}, 25^{\circ} \mathrm{C}\right)$ spectrum of compound 4.

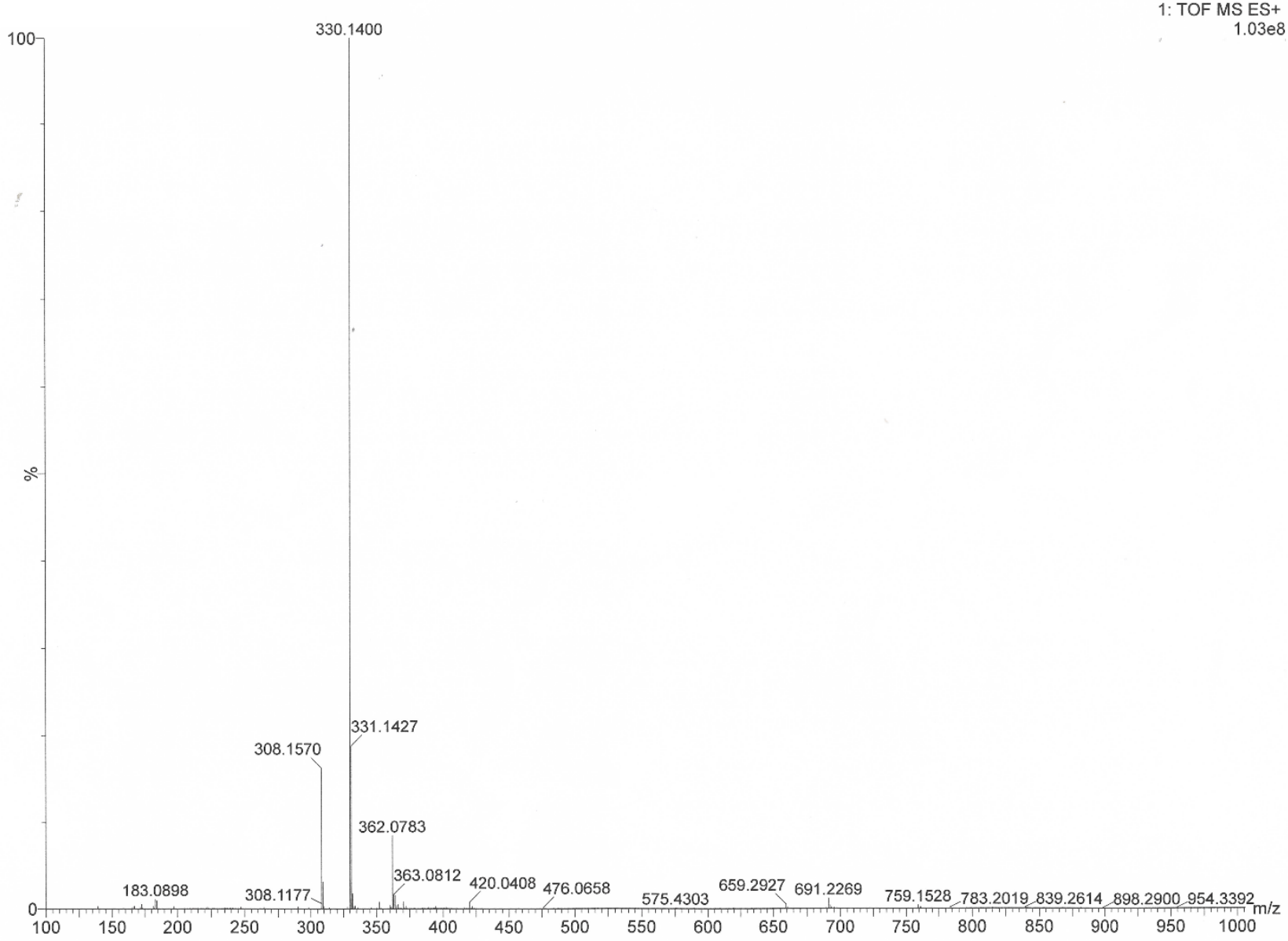

Figure S27: HRMS (ESI) spectrum of compound 4. 
Compound $5\left({ }^{1} \mathrm{H},{ }^{13} \mathrm{C},{ }^{19} \mathrm{~F}, \mathrm{HRMS}\right)$

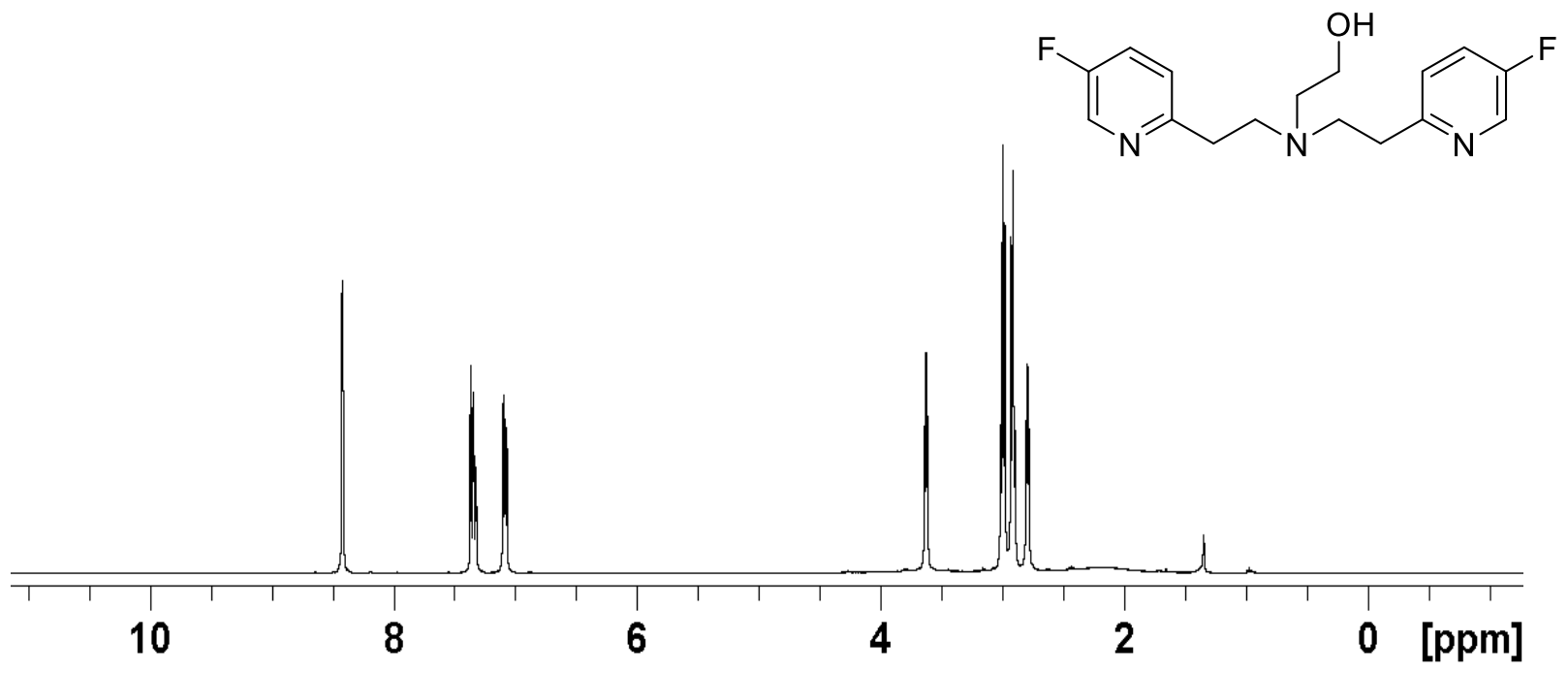

Figure S28: ${ }^{1} \mathrm{H}$ NMR $\left(400.35 \mathrm{MHz}, \mathrm{CDCl}_{3}, 25^{\circ} \mathrm{C}\right)$ spectrum of compound 5.

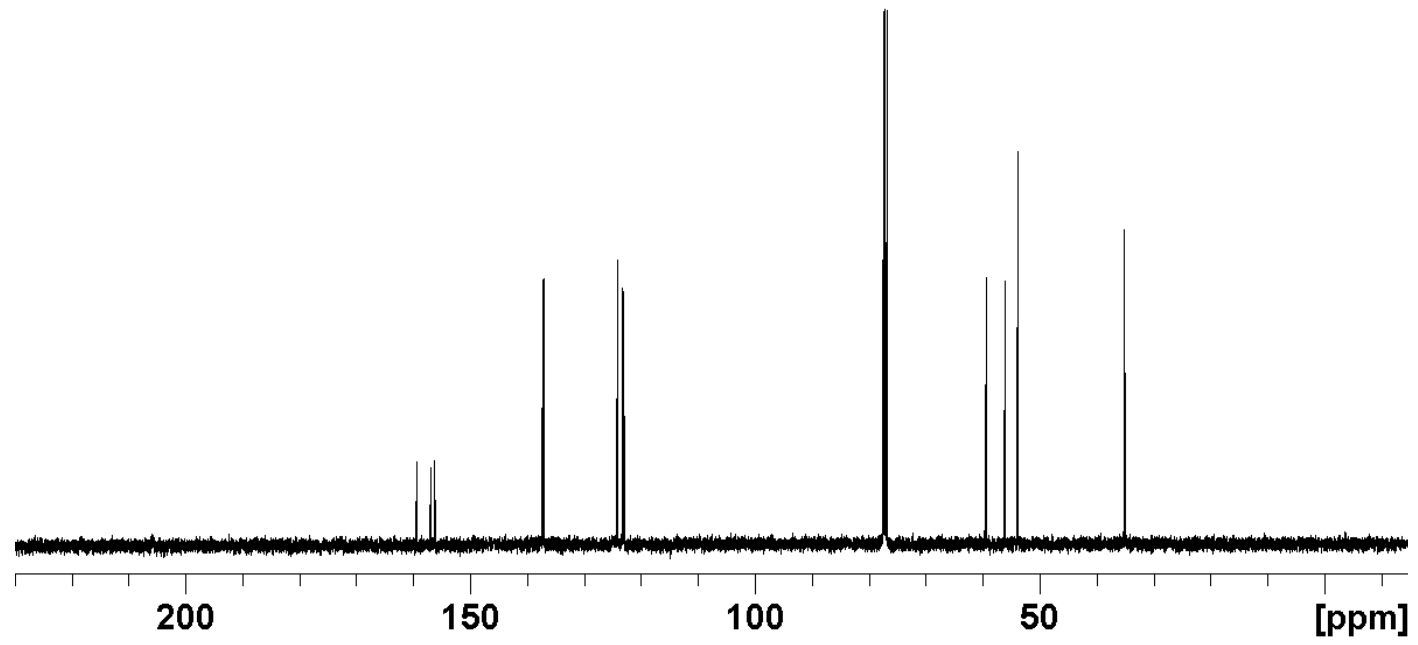

Figure S29: ${ }^{13} \mathrm{C}\left\{{ }^{1} \mathrm{H}\right\} \mathrm{NMR}\left(100.67 \mathrm{MHz}, \mathrm{CDCl}_{3}, 25^{\circ} \mathrm{C}\right)$ spectrum of compound $\mathbf{5}$. 


\begin{tabular}{|c|c|c|c|c|c|c|c|}
\hline \hline 110 & -120 & -130 & -140 & & [ppm] \\
\hline-110 & -120 & & &
\end{tabular}

Figure S30: ${ }^{19} \mathrm{~F} \mathrm{NMR}\left(376.7 \mathrm{MHz}, \mathrm{CDCl}_{3}, 25^{\circ} \mathrm{C}\right)$ spectrum of compound $\mathbf{5}$.

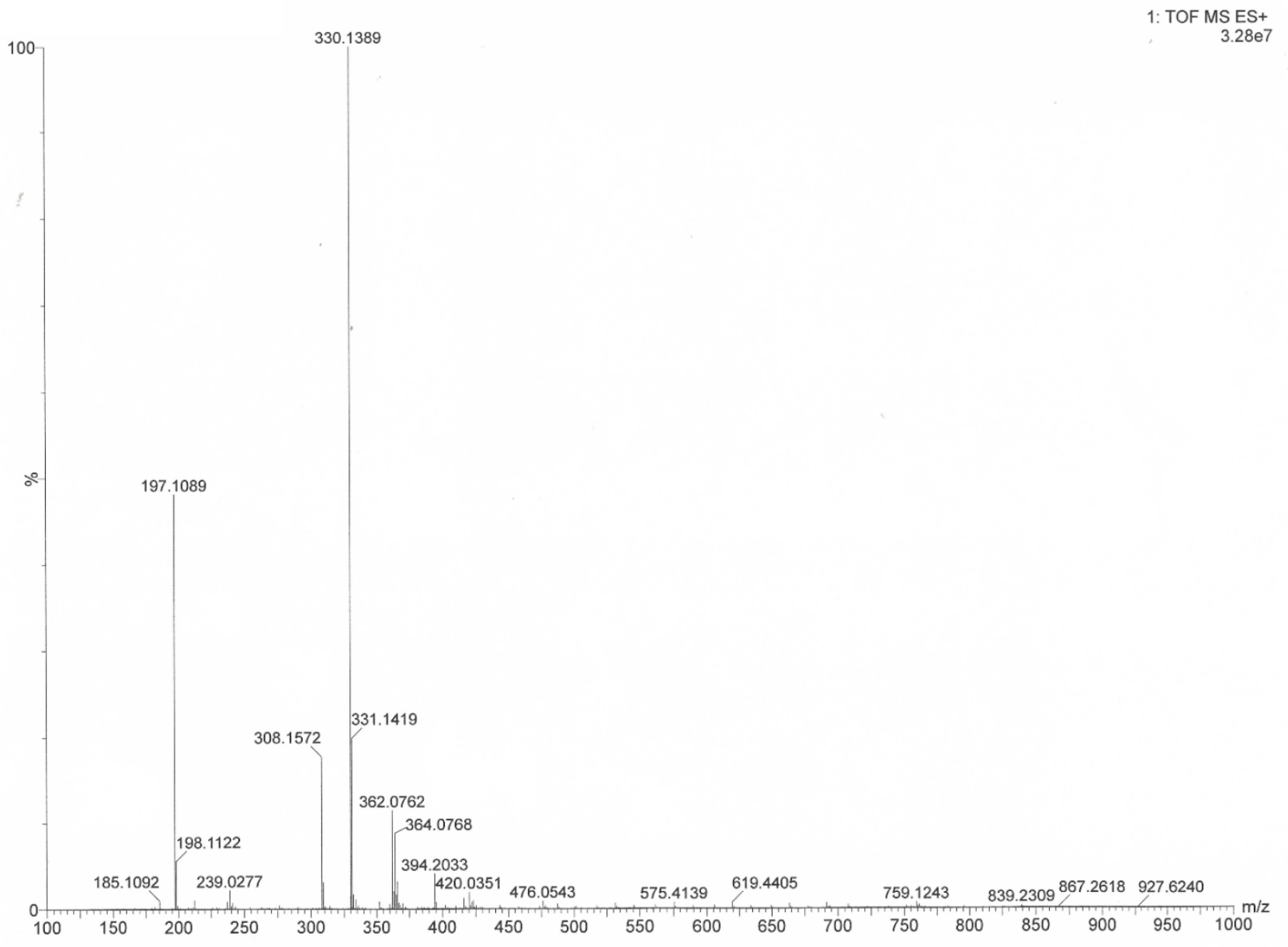

Figure S31: HRMS (ESI) spectrum of compound $\mathbf{5}$. 
Compound $6\left({ }^{1} \mathrm{H},{ }^{13} \mathrm{C},{ }^{19} \mathrm{~F}, \mathrm{HRMS}\right)$<smiles>Cc1nc(CCN(CCO)CCc2ccc(F)c(C)n2)ccc1F</smiles>

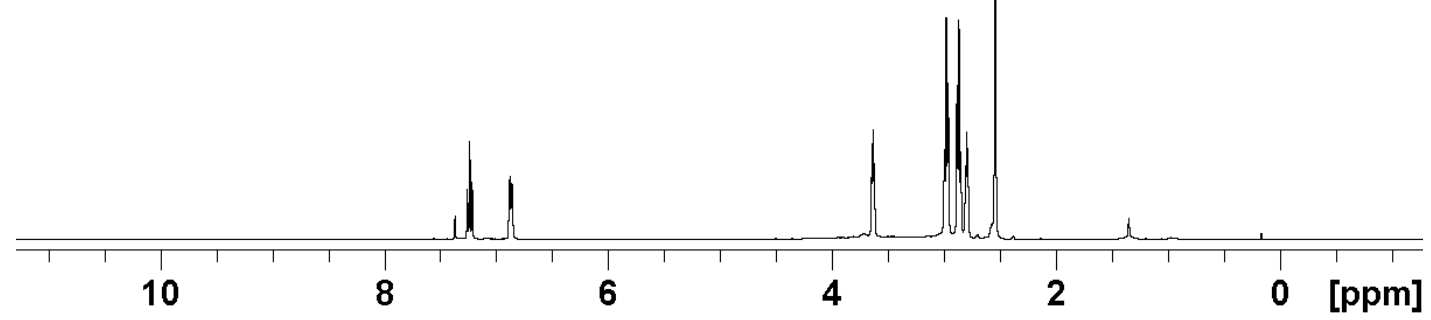

Figure S32: ${ }^{1} \mathrm{H}$ NMR $\left(400.35 \mathrm{MHz}, \mathrm{CDCl}_{3}, 25^{\circ} \mathrm{C}\right)$ spectrum of compound 6 .

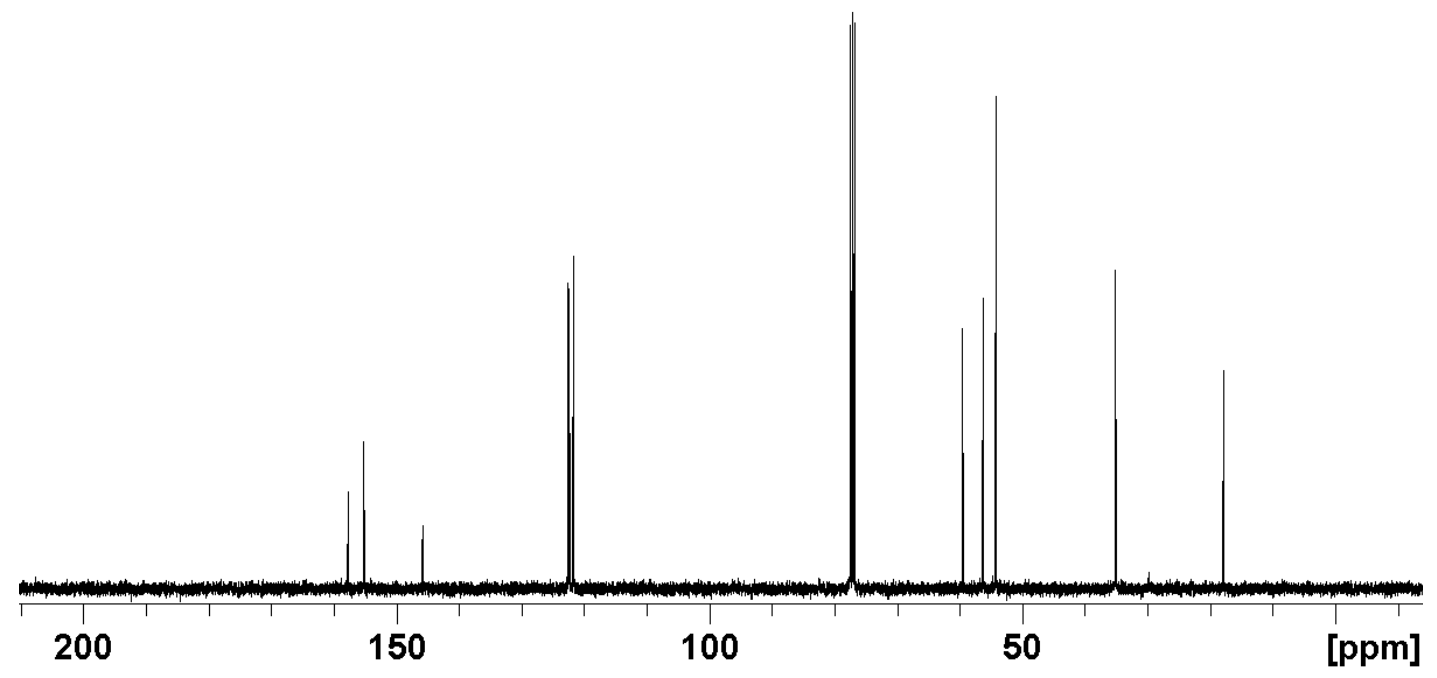

Figure S33: ${ }^{13} \mathrm{C}\left\{{ }^{1} \mathrm{H}\right\} \mathrm{NMR}\left(100.67 \mathrm{MHz}, \mathrm{CDCl}_{3}, 25^{\circ} \mathrm{C}\right)$ spectrum of compound 6. 


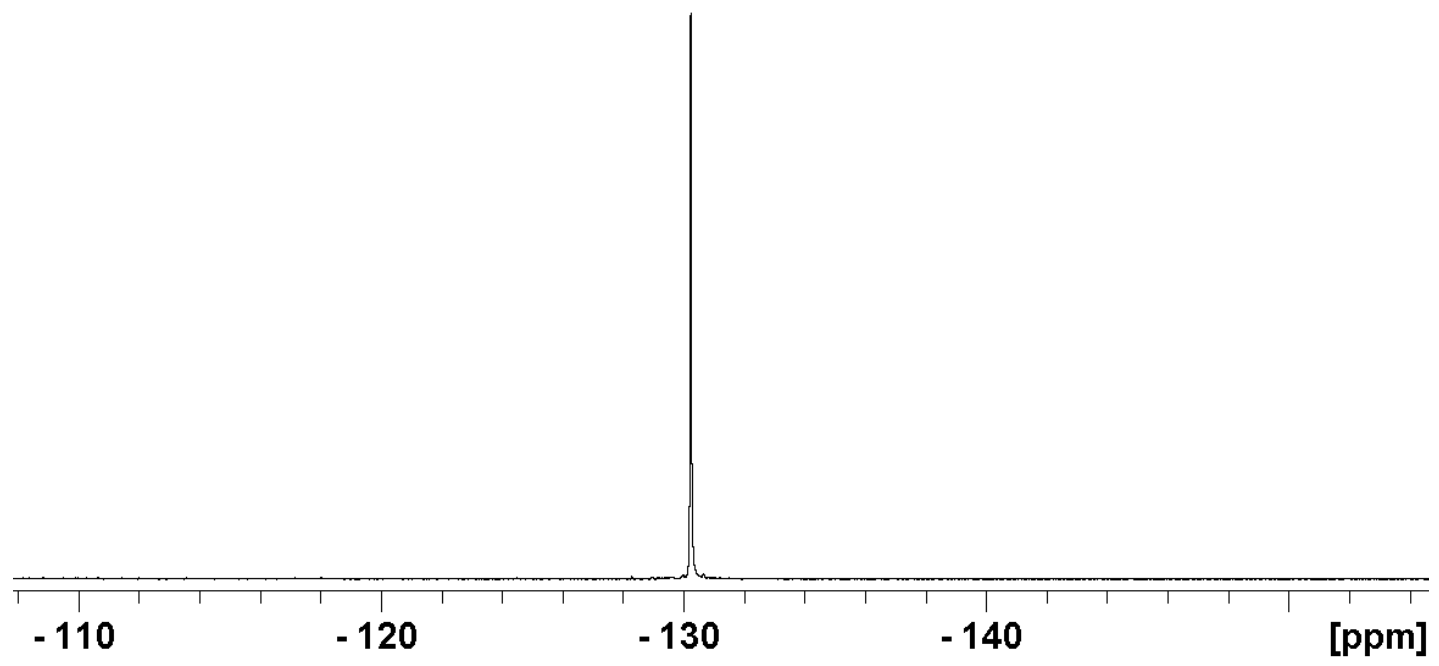

Figure S34: ${ }^{19} \mathrm{~F} \mathrm{NMR}\left(376.7 \mathrm{MHz}, \mathrm{CDCl}_{3}, 25^{\circ} \mathrm{C}\right)$ spectrum of compound 6.

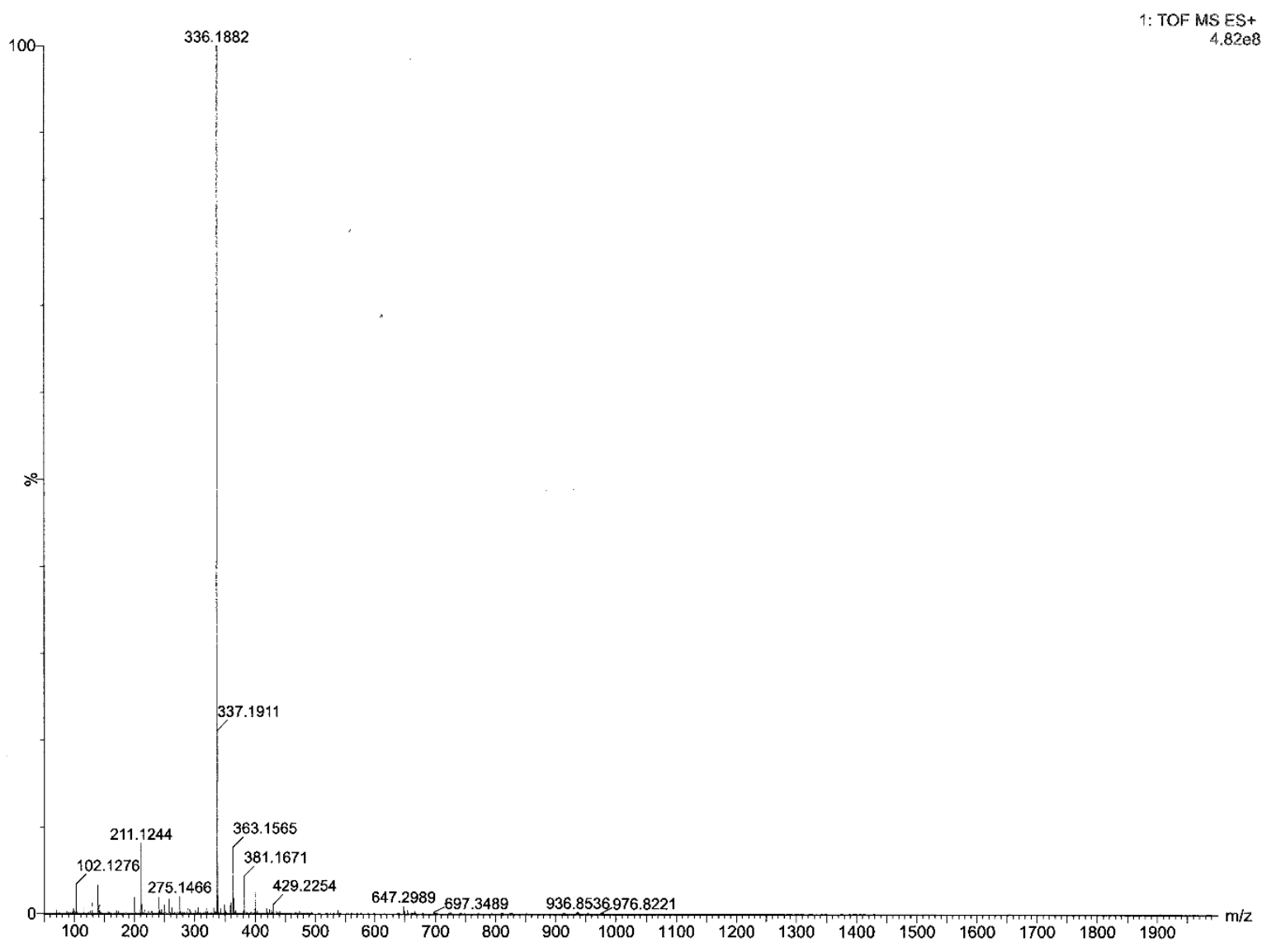

Figure S35: HRMS (ESI) spectrum of compound 6. 


\section{K. Crystallographic data}

Single crystals were obtained by slow evaporation of $\mathrm{MeOH}$. Data were collected after immersion of a crystal in paratone oil and immediate flash cooling under liquid nitrogen stream. Single crystal X-ray diffraction data were collected on a sealed tube Rigaku Synergy-S dual source diffractometer equipped with Dectris Pilatus3 $\mathrm{R}$ CdTe $300 \mathrm{~K}$ detector and microfocus, using Mo-Ka radiation (0.71073 $\AA$ ). Data collection was performed under LN at $100 \mathrm{~K}$. Data were processed with CrysAlis ${ }^{\mathrm{PRO}}$ and the structures were solved by direct methods using the SHELXT ${ }^{4}$. Refinement was performed based on $\mathrm{F}^{2}$ with SHELXL ${ }^{5}$ and OLEX2 ${ }^{6}$. Hydrogen atoms were assigned isotropic in riding mode. The twin structures were both two component twin structure with rotation of about $180^{\circ}$. Twin structures were first solved and refined against HKL4 reflection file and then further refined against the HKL5 reflections file. Crystallographic data and refinement parameters are shown as ORTEP (Oak Ridge Thermal Ellipsoid Plot) presentations in Figures S33-S37 and summarized in Supplementary Table S2.

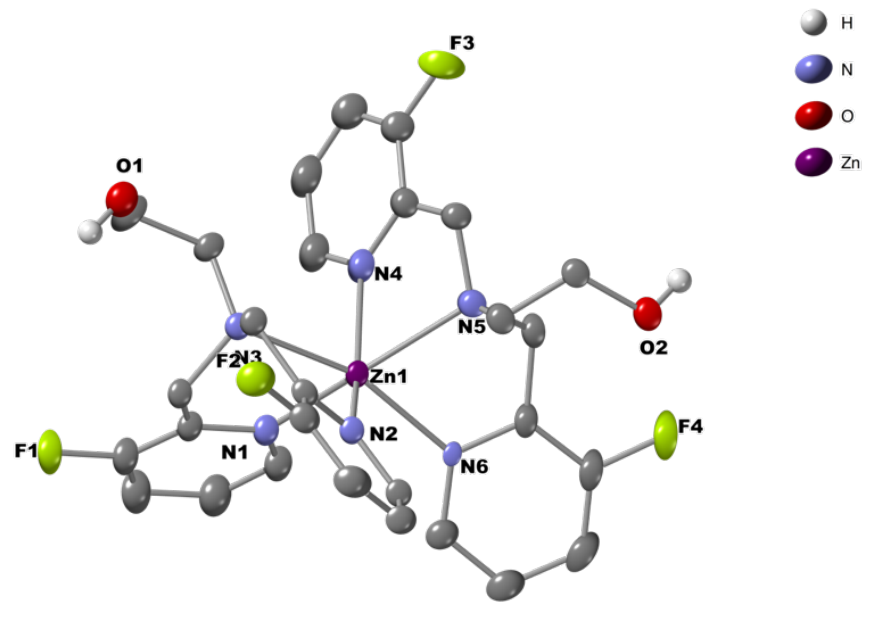

Figure S36. ORTEP representation of the crystal structure of $\mathbf{2}+\mathrm{Zn}$. Atoms are presented as thermal ellipsoids with $50 \%$ probability. Perchlorate counter ions and hydrogens are omitted for clarity. The hydroxy hydrogens are presented as spheres. 

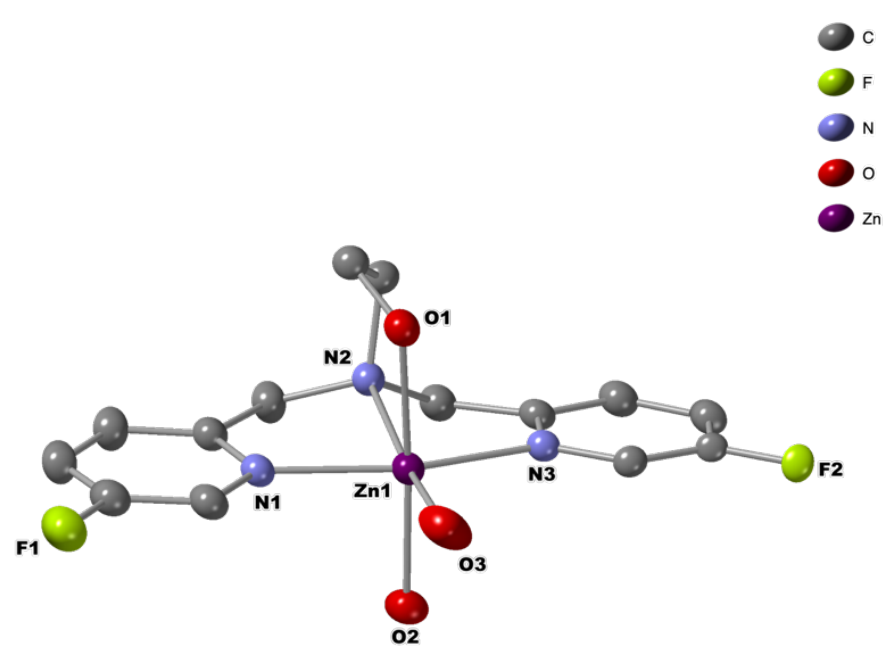

Figure S37. ORTEP representation of the crystal structure of $\mathbf{3}+\mathrm{Zn}$. Atoms are presented as thermal ellipsoids with $50 \%$ probability. Perchlorate counter ions and hydrogens are omitted for clarity.

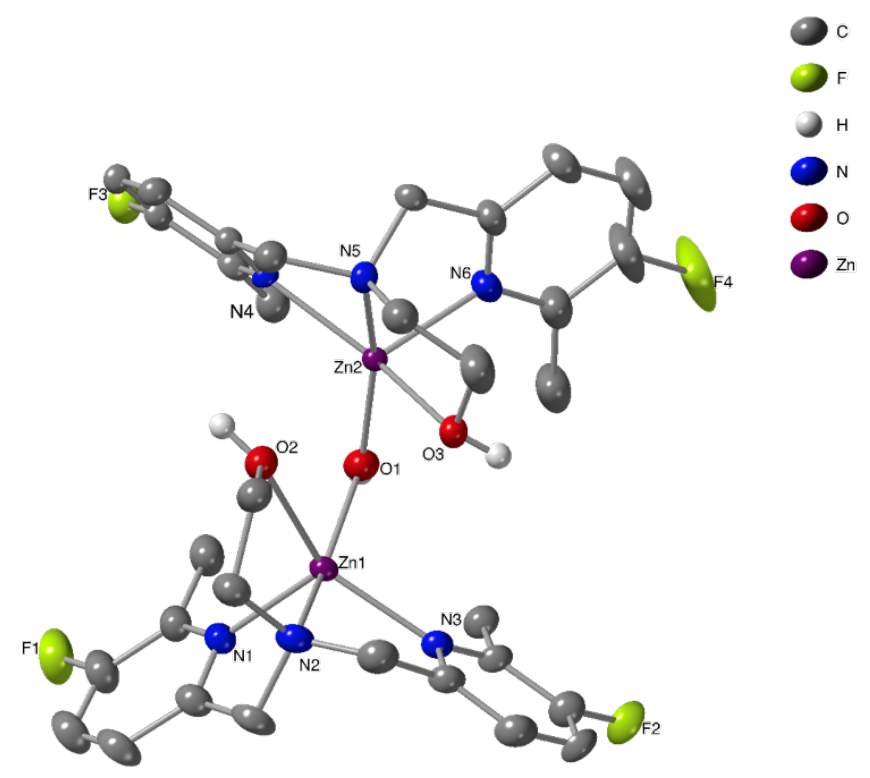

Figure S38. ORTEP representation of the crystal structure of $\mathbf{4}+\mathbf{Z n}$. Atoms are presented as thermal ellipsoids with $50 \%$ probability. Perchlorate counter ions and most of the hydrogens are omitted for clarity. Hydroxy hydrogens are presented as spheres. 


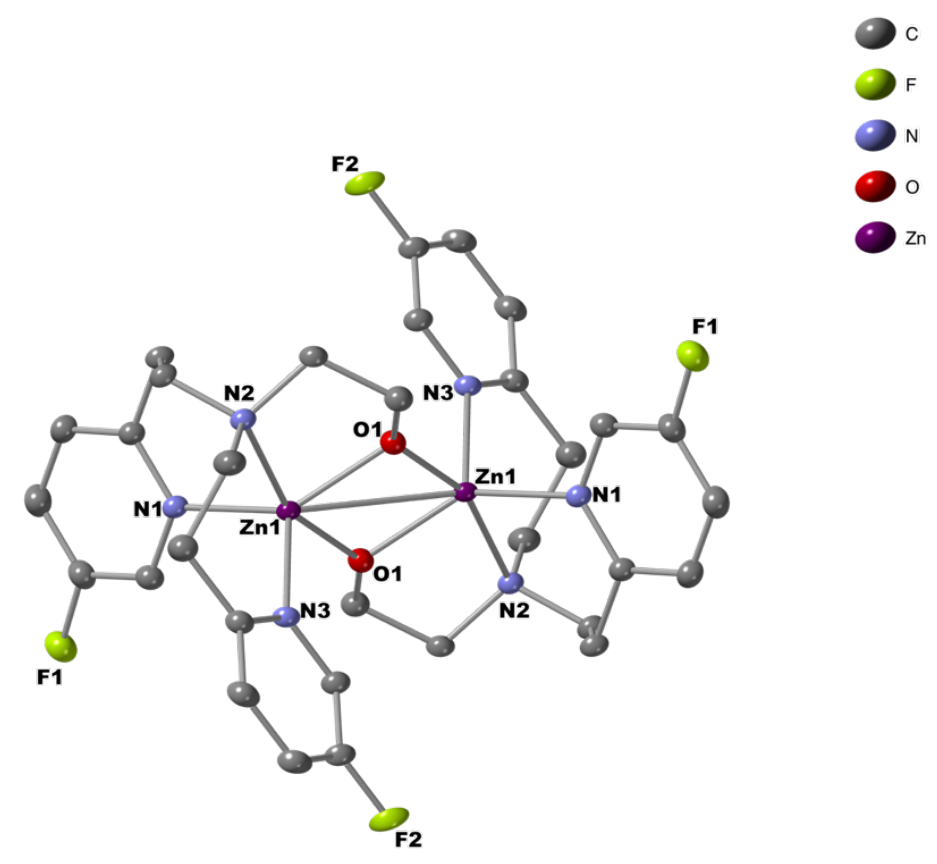

Figure S39. ORTEP representation of the crystal structure of $\mathbf{5}+\mathbf{Z n}$. Atoms are presented as thermal ellipsoids with $50 \%$ probability. Perchlorate counter ions and hydrogens are omitted for clarity.

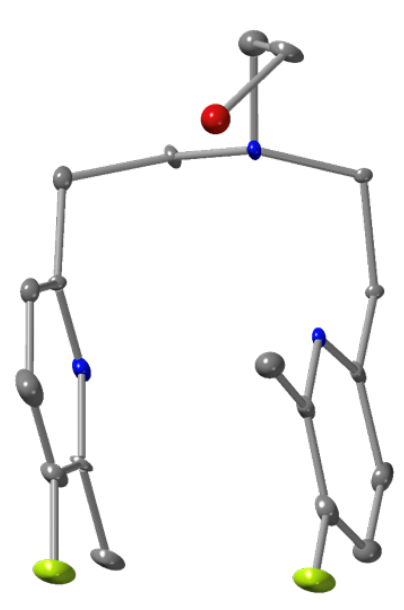

0
0
0
0

Figure S40. ORTEP representation of the crystal structure of 6 . Atoms are presented as thermal ellipsoids with $50 \%$ probability. Perchlorate counter ions and hydrogens are omitted for clarity. 
Table S2: Crystallographic data.

\begin{tabular}{|c|c|c|c|c|c|}
\hline Dataset & $\begin{array}{c}\text { Compound } \\
\mathrm{Zn}^{2+}\end{array}$ & $\begin{array}{l}\text { Compound } 4 \\
+\mathrm{Zn}^{2+}\end{array}$ & $\begin{array}{r}\text { Compound } 5 \\
+\mathrm{Zn}^{2+}\end{array}$ & $\begin{array}{l}\text { Compound } 2 \\
+\mathrm{Zn}^{2+}\end{array}$ & Compound 6 \\
\hline CCDC No. & 2084671 & 2084667 & 2084668 & 2084669 & 2084670 \\
\hline Formula & $\begin{array}{c}\mathrm{C}_{14} \mathrm{H}_{19} \mathrm{~F}_{2} \mathrm{~N}_{3} \mathrm{O}_{3} \mathrm{Z} \\
\mathrm{n}+2 \mathrm{ClO}_{4}+ \\
\mathrm{H}_{2} \mathrm{O}\end{array}$ & $\begin{array}{c}\mathrm{C}_{32} \mathrm{H}_{39} \mathrm{~F}_{4} \mathrm{~N}_{6} \mathrm{O}_{3} \\
\mathrm{Zn}_{2}+3 \mathrm{ClO}_{4}\end{array}$ & $\begin{array}{c}\mathrm{C}_{32} \mathrm{H}_{36} \mathrm{~F}_{4} \mathrm{~N}_{6} \mathrm{O}_{2} \\
\mathrm{Zn}_{2}+2 \mathrm{ClO}_{4}\end{array}$ & $\begin{array}{c}\mathrm{C}_{28} \mathrm{H}_{29} \mathrm{~F}_{4} \mathrm{~N}_{6} \mathrm{O}_{2} \mathrm{Z} \\
\mathrm{n}+2 \mathrm{ClO}_{4}\end{array}$ & $\begin{array}{l}\mathrm{C}_{18} \mathrm{H}_{24} \mathrm{~F}_{2} \mathrm{~N}_{3} \mathrm{O}+ \\
\mathrm{Cl}+1.967 \mathrm{H}_{2} \mathrm{O}\end{array}$ \\
\hline $\begin{array}{c}\text { Formula } \\
\text { weight }\end{array}$ & 597.61 & 1060.74 & 942.31 & 821.84 & 407.27 \\
\hline $\begin{array}{l}\text { Crystal } \\
\text { system }\end{array}$ & Monoclinic & Monoclinic & Monoclinic & Triclinic & Monoclinic \\
\hline Space group & $P 2_{1} / c$ & $P 2_{1} / n$ & $P 2_{1} / n$ & $P-1$ & $P 2_{1}$ \\
\hline $\begin{array}{c}\text { Crystal size } \\
(\mathrm{mm})\end{array}$ & $\begin{array}{l}0.143 \times 0.064 \\
\quad \times 0.056\end{array}$ & $\begin{array}{l}0.205 \times 0.078 \\
\quad \times 0.054\end{array}$ & $\begin{array}{l}0.122 \times 0.094 \\
\quad \times 0.022\end{array}$ & $\begin{array}{l}0.120 \times 0.095 \\
\quad \times 0.090\end{array}$ & $\begin{array}{c}0.245 \times 0.163 \\
\times 0.112\end{array}$ \\
\hline $\begin{array}{l}\text { Crystal color } \\
\text { and shape }\end{array}$ & $\begin{array}{l}\text { Colorless } \\
\text { prism }\end{array}$ & Colorless plate & Colorless plate & Colorless plate & $\begin{array}{l}\text { Colorless } \\
\text { prism }\end{array}$ \\
\hline $\begin{array}{c}\text { Temperature } \\
\text { (K) }\end{array}$ & 100 & 100 & 100 & 100 & 100 \\
\hline $\mathbf{a}(\AA)$ & $14.3912(4)$ & $12.34501(3)$ & $12.5355(4)$ & $9.9295(2)$ & $7.7177(1)$ \\
\hline b $(\AA)$ & $10.5859(4)$ & $15.4845(4)$ & $8.4622(3)$ & $10.0220(3)$ & $7.8077(1)$ \\
\hline$c(\AA)$ & $15.6685(5)$ & $21.5589(6)$ & $17.2728(5)$ & $16.9240(4)$ & $65.7902(6)$ \\
\hline$\alpha\left(^{\circ}\right)$ & 90 & 90 & 90 & $97.113(2)$ & 90 \\
\hline$\beta\left({ }^{\circ}\right)$ & 111.327(3) & $90.515(2)$ & $92.523(3)$ & $94.116(2)$ & $90.004(1)$ \\
\hline$Y\left({ }^{\circ}\right)$ & 90 & 90 & 90 & $94.536(2)$ & 90 \\
\hline Volume $\left(\AA^{3}\right)$ & $2223.54(13)$ & $4120.95(12)$ & $1830.49(10)$ & $1660.30(7)$ & $3964.35(8)$ \\
\hline $\mathbf{Z}$ & 4 & 4 & 2 & 2 & 8 \\
\hline$\rho_{\text {calcd }}\left(\mathrm{g} \mathrm{cm}^{-1}\right)$ & 1.785 & 1.710 & 1.710 & 1.644 & 1.365 \\
\hline$\mu\left(\mathrm{mm}^{-1}\right)$ & 1.429 & 1.452 & 1,542 & 0.988 & 0.234 \\
\hline $\begin{array}{l}\text { No. of } \\
\text { reflection } \\
\text { (unique) }\end{array}$ & 10637 (10637) & 79908 (9443) & 51836 (5579) & 15694 (15694) & 88050 (19629) \\
\hline $\mathbf{R}_{\text {int }}$ & & 0.1148 & 0.0705 & & 0.0410 \\
\hline $\begin{array}{c}\text { Completenes } \\
\text { s to } \theta(\%)\end{array}$ & 99.5 & 100.0 & 100.0 & 99.0 & 99.8 \\
\hline $\begin{array}{c}\text { Data I } \\
\text { restraints / } \\
\text { parameters }\end{array}$ & $10637 / 2 / 337$ & 9443 / 4 / 805 & 5579 / 0 / 353 & 15694 / 0 / 566 & 19629 / 2 / 946 \\
\hline $\begin{array}{l}\text { Goodness-of- } \\
\text { fit on } F^{2}\end{array}$ & 1.042 & 1.046 & 1.037 & 1.033 & 1.099 \\
\hline $\begin{array}{l}\text { Final } R_{1} \text { and } \\
w R_{2} \text { indices }[I \\
>2 \sigma(I)]\end{array}$ & $0.0518,0.1387$ & $0.0543,0.1179$ & $0.0330,0.0763$ & 0.0597, 0.1594 & $0.0578,0.1237$ \\
\hline $\begin{array}{c}R_{1} \text { and } w R_{2} \\
\text { indices (all } \\
\text { data) }\end{array}$ & $0.0669,0.1505$ & $0.0696,0.1240$ & $0.0458,0.0807$ & $0.0912,0.1834$ & $0.0766,0.1336$ \\
\hline $\begin{array}{l}\text { Largest diff. } \\
\text { peak and hole } \\
\left(\mathrm{e} / \AA^{3}\right) \\
\end{array}$ & $1.308,-0.661$ & $1.143,-0.845$ & $0.472,-0.505$ & $1.020,-1.097$ & $0.533,-0.418$ \\
\hline
\end{tabular}




\section{Supplementary references}

1. Zaiss, M.; Bachert, P., Exchange-dependent relaxation in the rotating frame for slow and intermediate exchange - modeling off-resonant spin-lock and chemical exchange saturation transfer. NMR in Biomedicine 2013, 26 (5), 507-518.

2. Zaiss, M.; Zu, Z.; Xu, J.; Schuenke, P.; Gochberg, D. F.; Gore, J. C.; Ladd, M. E.; Bachert, P., A combined analytical solution for chemical exchange saturation transfer and semi-solid magnetization transfer. NMR in Biomedicine 2015, 28 (2), 217-230.

3. Zaiss, M.; Angelovski, G.; Demetriou, E.; McMahon, M. T.; Golay, X.; Scheffler, K., QUESP and QUEST revisited - fast and accurate quantitative CEST experiments. Magn Reson Med 2018, 79 (3), 1708-1721. 